\title{
ANCESTRAL, ORACULAR AND PROPHETIC AUTHORITY: "SCRIPTURAL AUTHORITY" ACCORDING TO PAUL AND PHILO
}

\author{
George H. van Kooten
}

\section{InTRODUCTION}

In this paper I would like to argue that Paul's view on the authoritative Jewish writings, the "holy writings," as he calls them (Rom 1:2), is rather nuanced and subtle. ${ }^{1}$ For Paul, the fact that these writings are called "holy" does not imply that they are divinely revealed in their entirety and for that reason authoritative and holy. As I will demonstrate, these writings are considered authoritative for a variety of reasons, firstly because they are the ancestral writings of the Jews, in the same way as the ancestral writings of others in Greco-Roman antiquity were considered authoritative. This will be explored in section one.

Secondly, in Paul's view, some parts of the Jewish writings are more authoritative than others insofar as they contain the direct divine oracles of God, normally rendered in direct divine speech and addressed to the prophets who record them. This divine, oracular authority will be explored in section two.

Thirdly, the question that then arises is in what sense the prophets, and in particular their writings, are related to God's oracles, which are encompassed by the prophetic writings. We will look at Philo, who seems to have reflected theoretically on the difference between oracular and prophetic authority and who provides a close analogy for Paul's more implicit views on the issue. This is the subject of section three.

Finally, if Paul has such a nuanced view of the multilayered authority of the Jewish writings, we need to understand how this is related both to the well-known view expressed in 2 Tim 3:16, generally

${ }^{1}$ I wish to express my thanks to the participants in this colloquium for their criticism and suggestions, especially Jan Bremmer, Piet van der Horst, Arie van der Kooij, Hindy Najman, and Eric Peels.

(C) GEORGE H. VAN KOOTEN, 2010 | DOI:10.1163/9789004190740_016

This is an open access chapter distributed under the terms of the CC BY-NC-ND 4.o license. 
believed to be a later Pseudo-Pauline pseudepigraphon, that "all Scripture is inspired by God" and to other concepts in Paul's writings such as "the word of God" and "revelation." Whereas the later notions do not seem to contradict Paul's concise and discerning differentiations between ancestral, oracular and prophetic authority, it appears that the more rigid, monolithic view of 2 Tim 3:16 was made as a counterclaim against an emerging gnostic way of thinking which denied the authoritative status of particular writings. Although 2 Timothy's position is understandable in such a polemical context, it would be wrong, I would suggest, to mistake this for Paul's understanding of the authoritative Jewish writings. His nuanced approach still reflects and has much in common with a general Jewish and Greco-Roman appreciation of the importance of ancestral writings and the special status of divine oracles, of which the prophets were the recipients and interpreters.

\section{Human and Ancestral Authority}

\subsection{References to Moses, David and Isaiah as Human Authorial Names}

Firstly we will discuss Paul's reference to the human and ancestral aspect of his appreciation of the Jewish Scriptures as authoritative writings. On several occasions, Paul refers to figures such as Moses, David and Isaiah in their capacity as human authors. In these instances he does not refer to the "holy writings" but uses their names as authorial names. In relation to David and Isaiah, it seems clear that they are regarded as human authors to whom one can refer. Paul explicitly refers to David twice as the author of a subsequent quotation in his writings: in Rom 4:6-8 Paul quotes Ps 31:1-2 and in Rom 11:9-10 he quotes Ps 68:23-24. On both occasions Paul introduces the quota-

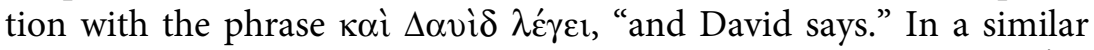

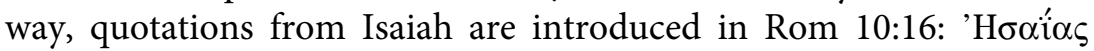

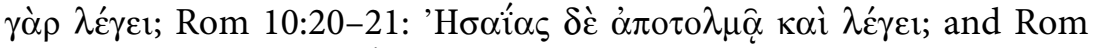

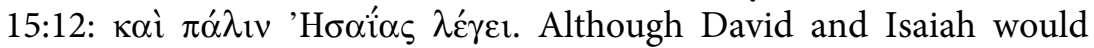
have been held in high esteem by Paul, it seems that in these passages he considers them as human authors of authoritative writings, without implying or referring to the holy or divine nature of their 
writings. These writings seem to be authoritative because they derive from revered ancestors.

This is particularly clear in the case of Moses. In many instances Paul credits Moses as the author of a particular passage which he quotes. Paul qualifies these passages either by means of the formula $\dot{o}$ vómos $\lambda \varepsilon_{\varepsilon} \varepsilon \varepsilon$, "the Law says," implying it is the Mosaic law he refers to, or by mentioning Moses by name. In the latter cases he introduces quotes

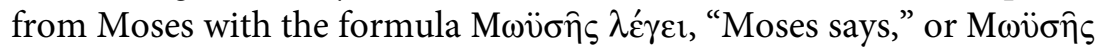

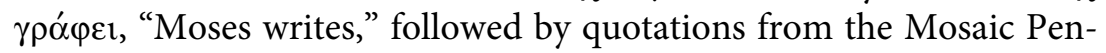
tateuch, Exodus, Leviticus and Deuteronomy. ${ }^{2}$

A very interesting case is Rom 10:5-8, in which Paul differentiates between Moses as the one who describes "the righteousness that comes from the Law" and those passages, all but one drawn from Moses, which concern "the righteousness that comes from faith." In this way Paul distinguishes two layers within the Jewish writings, a positive, still useful perspective and another less positive, disputable perspective, both of which are part and parcel of the same collection of predominantly Mosaic writings:

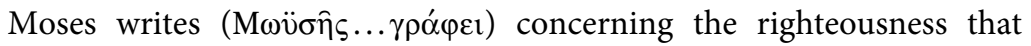
comes from the Law, that 'the person who does these things will live by them' (Lev 18:5). But the righteousness that comes from faith says, 'Do not say in your heart (Deut 9:4), "Who will ascend into heaven?" (Deut 30:12)' (that is, to bring Christ down) 'or "Who will descend into the abyss?" (Ps 107:26)' (that is, to bring Christ up from the dead). But what does it say? 'The word is near you, on your lips and in your heart (Deut $30: 14$ )' (that is, the word of faith that we proclaim). (Rom 10:5-8)

In this passage, Paul differentiates between two perspectives within the Mosaic law. Although together they constitute "the entire Law," a concept used in Gal 5:3 (cf. Gal 5:14), it is noteworthy that Paul explicitly credits the negative view-that righteousness comes from the Law-to Moses, whereas the other, positive view about the righteousness that comes from faith, which is predominantly based on Moses, is nevertheless not ascribed to him explicitly. The simple reason for this might be that Paul also emphasizes the positive view with a reference to one of the many non-Mosaic Psalms (Ps 107:26). Be this as it may, for

${ }^{2}$ See Rom 10:5-8 (= Lev 18:5; Deut 9:4; Deut 30:12, 14) and Rom 10:19 (= Deut 32:21). Cf. Rom 9:15 (= Exod 33:19). 
our present study it is relevant that Paul points to a tension within the Jewish Scriptures that he refers to; in his view, two very differing views are present in the same Mosaic writings. This tension, it seems, can be accepted with little difficulty if there is also a human aspect to these writings.

\subsection{The Formula "the Law Says": A Reference to an Authoritative Ancestral Law}

On other occasions Paul refers to the Mosaic writings without mentioning Moses by name, instead using the formula o vó $\mu$ os $\lambda \varepsilon^{\prime} \gamma \varepsilon$. He uses it various times: in 1 Cor 7:7, 9:8-9, 14:34 and Rom 3:19. ${ }^{3}$ The way in which he refers to the Mosaic law clearly implies that the Law being referred to is authoritative, but it says nothing about the exact status of the writing, that is, whether it is considered human, divine or inspired. Rather it seems only authoritative because it is ancestral. This becomes particularly clear when we realize that the phrase $\dot{\delta}$ vónos $\lambda \varepsilon \gamma_{\varepsilon 1}$ was also a common formula in pagan Greek. ${ }^{4}$ One of its earliest occurrences is in Plato's Republic and Laws.

In Resp. 451b Socrates states that he believes "that involuntary homicide is a lesser fault than to mislead opinion about the honourable, the good, and the just" and for that reason he is hesitant to enter into a discussion with Glaucon, if he would indeed be deemed to deceive him. Glaucon, however, reassures him and answers that even if there was a false note in the argument he would "release" Socrates "as in a homicide case," and thus urges him to continue with confidence. Socrates replies:

Well, said I, he who is released in that case is counted pure, as the law

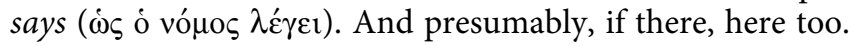

${ }^{3}$ In Rom 3:19 Paul uses it in a general sense to refer to what the Law has to say.

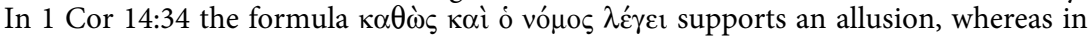
the other cases it introduces a quotation (1 Cor 7:7; 9:8). In the former of the last two passages, the actual formula reads ó vó $\mu$ o $\varsigma$ है $\lambda \varepsilon \gamma \varepsilon v$ (1 Cor 7:7) and in the latter passage

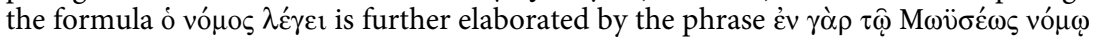
$\gamma \varepsilon$ ' $\rho \propto \alpha \tau \tau \alpha$ : "Do I say this on human authority? Does not the Law also say the same? For it is written in the law of Moses" (1 Cor 9:8-9).

${ }^{4}$ Cf. H.W. Hollander, 'The Meaning of the Term 'Law' (NOMOS) in 1 Corinthians," NovT 40 (1998): 117-35 (122 n. 25). 
The phrase $\dot{\omega} \varsigma \delta$ vó $\mu \circ \varsigma \lambda \varepsilon^{\prime} \gamma \varepsilon$ is used in this case to express the regulation stated by the law that someone who is "released" is considered pure.

The expression is regularly used by Plato in various contexts. Discussing an example of a good and reasonable man who has lost his son, Plato introduces the view that "reason and law" exhort such a man to resist his grief, whereas his emotions urge him to give way to his grief, such that there are two opposite impulses operating in him. The deadlock is overcome only if the man is prepared to follow the guidance of "the law":

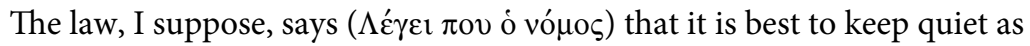
far as possible in calamity and not to chafe and repine, because we cannot know what is really good and evil in such things and it advantages us nothing to take them hard, and nothing in mortal life is worthy of great concern. (Resp. 604b)

Once again, Plato uses the phrase $\Lambda \varepsilon^{\prime} \gamma \varepsilon 1 \ldots$ ó vónos. As in the previous case, Plato clearly refers to an authoritative law which people are bound or prepared to follow, but his reference says nothing about the divine status of the law under consideration. The most one can say is indeed that this law is considered to be authoritative.

The reason why it is authoritative might be made clear in Plato's Laws, where the law referred to is explicitly qualified as ó vónos ó $\pi$ ó $\tau \rho ı \varsigma$, , "the ancestral law":

That which is the real self of each of us, and which we term the immortal soul, departs to the presence of other gods, there-as the ancestral law

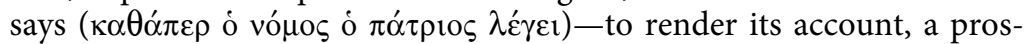
pect to be faced with courage by the good, but with uttermost dread by the evil. (Leg. 959b)

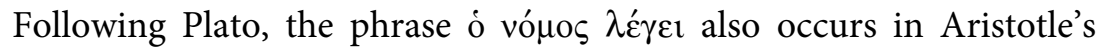
writings ${ }^{5}$ and is frequently used by orators such as Isaeus, Demosthenes, Aeschines and Hyperides from the fifth and fourth centuries B.C.E., ${ }^{6}$ and continues to be applied in the centuries to follow. ${ }^{7}$ However, what captivates our attention most now is the specific way in

\footnotetext{
${ }^{5}$ Aristotle, Rhet. 1375b18.

${ }^{6}$ See Isaeus, De Pyrrho 68; Demosthenes, Andr. 6, 20; 1 Boeot. 12; Aeschines, Tim. 13; Hyperides, Ath. 6.6.

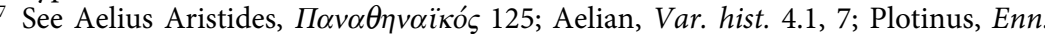
3.2.9; Apsines, Rhet. 372. See, for Jewish sources, also 4 Macc. 2:5 and Philo, Det. 159; Deus 99.
} 
which Plato qualifies this law as ancestral: "as the ancestral law says." This phrase makes us aware that what renders the law authoritative is its ancestral, traditional nature and its time-honoured character, the fact that it was already binding, or thought to have been binding, for the previous generations. Indeed the notion of "the ancestral law"

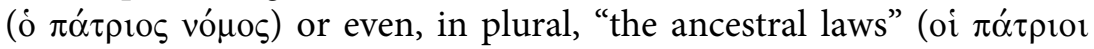
vómot) proliferates in both Greek pagan sources and in Jewish sources of the Greco-Roman era. It is not only found in such wide-ranging Greco-Roman pagan authors as Thucydides, Herodotus, Isocrates, Xenophon, Plato, Demosthenes, Aristotle, Polybius, Diodorus Siculus, Dionysius Halicarnassensis, Strabo, Plutarch, Arrianus, Appian, Lucian, Aelius Aristides, Athenaeus, Cassius Dio, Sextus Empiricus, Philostratus, Porphyrius and Julianus, ${ }^{8}$ but it also occurs in the writings of Jewish authors such as the author of 2 Macc, Philo and Josephus. ${ }^{9}$ The topic is also debated by Christian authors, notably by Origen, who answers the charge brought against the Christians by Celsusthat they destroy the paternal laws and traditions which each nation follows. ${ }^{10}$ All these authors, pagan, Jewish and Christian, attest to the

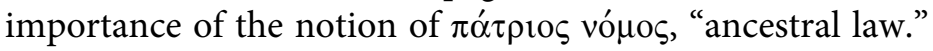

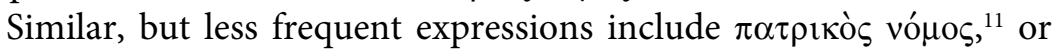

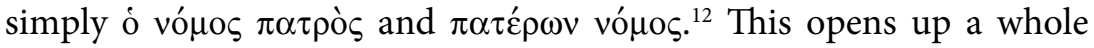
field of ancestral authorities. It is not only the law that can be regarded as ancestral, since traditions and writings are also depicted as ances-

8 Thucydides, Hist. 2.34.1; 4.118.1-3; 8.76.6; Herodotus, Hist. 3.82; Isocrates, Paneg. 55; Panath. 169; Xenophon, Anab. 2.3.2; 5.2.14; 6.5.7; 7.8.5; Plato, Leg. 680a; 793a; 959b; Epin. 985d; Demosthenes, Mid. 52; Aristotle, Ath. 29.3; Pol. 1268b; Diod. Sic. 14.65.2; 16.24.5; 17.110.5; 40.2.1; Dionysius Halicarnassensis, Ant. rom. 2.65.3; 4.84.5; 15.9.6; Strabo, Geogr. 15.1.64; 17.3.24; Plutarch, Alex. 69.8; Sert. 22.5; Arrian, Anab. 3.16.9; Appian, Mith. 279, Bell. civ. 2.7.47; 2.10.63; 3.7.44; 5.13.128; Lucian, Phal. 2.9;

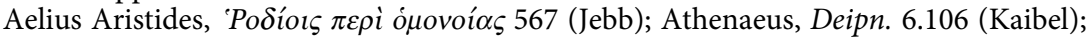
Cassius Dio, Hist. rom. 54.9.10; Sextus Empiricus, Math. 11.166; Philostratus, Ep. 1.5; Porphyry, Abst. 4.22; Julianus, Ep. 89b line 377.

9 See 2 Macc 6:1; 7:2; 7:37; 4 Macc. 4:23; 5:33; Philo, Spec. 2.13; Prob. 80; Hypoth. 195; QE frg. 14; Josephus, Vita 135; C. Ap. 2.143; A.J. 4.71; 4.130; 5.108; 7.130; 7.131; $7.374 ; 8.362 ; 9.243 ; 10.11 ; 10.214 ; 11.110 ; 11.140 ; 11.231 ; 11.338 ; 12.142 ; 12.146$; $12.240 ; 12.267 ; 12.300 ; 12.381 ; 12.382 ; 14.235 ; 14.242 ; 16.163 ; 16.365 ; 17.149 ; 17.150$; $18.84 ; 18.236 ; 18.264 ; 18.280 ; 19.301 ; 19.349 ; 20.218 ;$ B.J. 1.108; $1.209 ; 1.650 ; 1.653 ; 2.7$; $2.86 ; 2.192 ; 2.393 ; 3.356 ; 6.334 ; 7.357$.

10 Origen, Cels. 2.1-4; 5.25-43.

11 Cratinus, frg. 116; Dionysius Halicarnassensis, Ant. rom. 12.16.4; Athenaeus, Deipn. 15.6 (Kaibel).

12 Sophocles, Aj. 548-549; Plato, Criti. 120b; Xenocrates, frg. 222 = Plutarch, Def. orac. 416C; Prov (LXx) 6:20; Philo, Ebr. 84; Plutarch, Def. orac. 436F. 
tral and hence authoritative. Some examples of passages referring to ancestral traditions and writings in both pagan and Jewish sources in Greek are useful here, as they reveal to us the importance of ancestry in the way authority is constructed. In his Deipnosophists Athe-

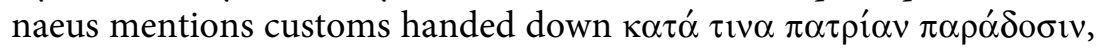
"by ancestral tradition" (3.97 Loeb $=3.52$ Kaibel). It is these kinds of traditions that Paul has in view when he describes his pre-Christian Jewish past:

You have heard, no doubt, of my earlier life in Judaism. I was violently persecuting the church of God and was trying to destroy it. I advanced in Judaism beyond many among my people of the same age, for I was far more zealous for the traditions of my ancestors ( $\tau \hat{\omega} v \pi \alpha \tau \rho \iota \kappa \hat{v} v \mu \mathrm{ov}$ $\pi \alpha \rho \alpha \delta$ ó $\varepsilon \varepsilon \omega v)$. (Gal 1:13-14)

This description of Judaism as characterized by ancestral traditions accords very well with the report of Paul's Pharisaic education in Acts 22:3, according to which Paul was "brought up at the feet of Gamaliel, educated strictly according to the ancestral law" ( That indeed, particularly in Pharisaic Judaism, the transmission of ancestral laws was paramount, is confirmed by Josephus' outline of the Pharisaic position, in contrast with that of the Sadducees:

For the present I wish merely to explain that the Pharisees had passed to

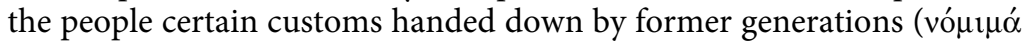

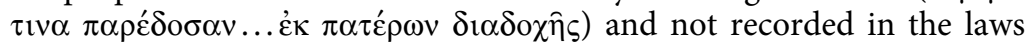

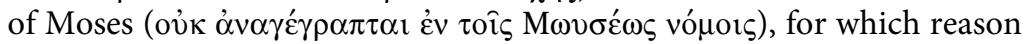
they are rejected by the Sadducaean group, who hold that only those regulations should be considered valid which were written down (in Scripture), and that those which had been handed down by the ancestors

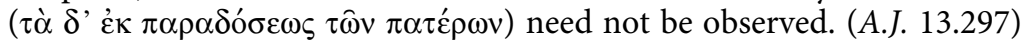

In the writings of Greco-Roman authors, both pagan and Jewish, laws and traditions gain much authority if they are ancestral. According to the Jewish author of the Wisdom of Jesus ben Sira, ancestral origins also explain why particular books are appreciated. According to the introduction, in which the author explains why he wishes to translate a book by his grandfather from Hebrew into Greek, the author states that his grandfather had devoted himself to "the Law and the Prophets and the other books of our ancestors":

Many great teachings have been given to us through the Law and the Prophets and the others (or: the other books) that followed them, and for these we should praise Israel for instruction and wisdom. Now, those 
who read the Scriptures must not only themselves understand them, but must also as lovers of learning be able through the spoken and written word to help the outsiders. So my grandfather Jesus, who had devoted himself especially to the reading of the Law and the Prophets and the

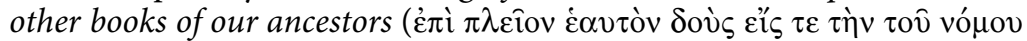

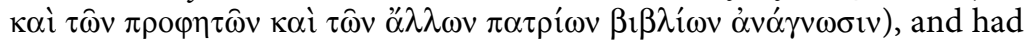
acquired considerable proficiency in them, was himself also led to write something pertaining to instruction and wisdom, so that by becoming familiar also with his book those who love learning might make even greater progress in living according to the Law. (Prologue)

In this quote it is clear that the writings of the Mosaic law, the prophets "and the other ancestral books" are authoritative for Jesus and his grandson precisely because they are the books of the Jewish ancestors. Because they are ancestral, they are worthy of respect. This also seems to imply that if these writings are authoritative because of their ancestral nature, there may be clear ethnic limitations with respect to their authority. Just as Plato refers to what the ancestral law says, Ben Sira mentions with reverence the ancestral books of the Jews, as do other authors with respect to different ancestral traditions. For such laws, traditions and books to be appreciated, it was not necessary to state that they were the product of divine revelation. It was sufficient that they were ancestral for them to be appreciated.

However, not everyone took an uncritical stance towards ancestral writings. Cicero, for example, differentiated between ancestral civil law-the ethnically determined laws of the nations-on the one hand, and the law of nature-the universal law-on the other. According to Cicero, it is possible that something:

... is neither by custom accounted morally wrong nor forbidden either by statute or by civil law; nevertheless it is forbidden by the moral law (neque more turpe haberi neque aut lege sanciri aut iure civili, tamen naturae lege sanctum est). For there is a bond of fellowship-although I have often made this statement, I must still repeat it again and againwhich has the very widest application, uniting all men together and each to each. This bond of union is closer between those who belong to the same nation, and more intimate still between those who are citizens of the same city-state. It is for this reason that our forefathers chose to understand one thing by the universal law and another by the civil law; the civil law is not necessarily also the universal law, but the universal law ought to be also the civil law (Itaque maiores aliud ius gentium, aliud ius civile esse voluerunt; quod civile, non idem continuo gentium, quod autem gentium, idem civile esse debet). But we possess no substantial, life-like image of true Law and genuine Justice; a mere outline sketch is 
all that we enjoy. I only wish that we were true even to this; for, even as it is, it is drawn from the excellent models which Nature and Truth afford. (Off. 3.69)

In Cicero's view there is a difference between the moral, natural law (the naturae lex), which should govern all nations, that is, the law of the nations or the universal law (ius gentium), and the specific ancestral and ethnic set of laws of those who belong to the same nation, the ius civile. Insofar as Cicero states that "the universal law ought to be also the civil law," he is critical of ethnic, ancestral law. Hindy Najman has shown that Philo was acquainted with this debate but developed a rather surprising view. Whereas Cicero believed the civil law to be only a faint copy of the true natural law and for that reason remained sceptical about the precise relationship between them, according to Philo the ethnic law of the Jewish nation is identical to the law of nature. As Najman states:

For the Hellenistic thinkers who developed the concept of the law of nature, no written civil law could be more than a shadow and appearance of the original.... So Philo would have to show in opposition to Greek thought on the topic, that the perfect and authoritative copy of the law of nature was to be found... in the written law of Moses, despite its writtenness and despite its apparent particularity. ${ }^{13}$

And that is what Philo did. For, according to Najman:

... his central theme is that a unique status must be accorded to one collection of written laws, the Law of Moses, which is the law of a particular nation. These laws are unique. They remain 'firm, unshaken, immovable, stamped as it were, with the seals of nature herself.' ${ }^{14}$

It seems that Paul, by contrast, prefers Cicero's scepticism regarding the unrestricted validity of ethnic ancestral laws. Paul, having characterized his Jewish Pharisaic education as instruction in ancestral traditions (Gal 1:14), is very critical about the temporal and hence arbitrary nature of the Jewish law (Gal 3:17), promulgating instead "the law of Christ" (Gal 6:2), which is not ethnic but derives from a particular individual. At the same time, Paul is very positive about the

${ }^{13}$ H. Najman, "The Law of Nature and the Authority of Mosaic Law," SPhilo 11 (1999): 55-73 (59).

${ }_{14}$ H. Najman, "A Written Copy of the Law of Nature: An Unthinkable Paradox?" SPhilo 15 (2003): 54-63 (57-58), with reference to various proof texts in Philo. 
possibility of non-Jewish nations following the law of nature, despite the fact that they are ignorant of the Jewish law (Rom 2:14). In that sense, both Cicero and Paul are critical of the unquestioned validity of ethnic ancestral laws.

As a rule, however, we have seen that the ancestry of particular laws, traditions and books greatly enhanced their authority. The sources quoted above show that laws are often qualified as "ancestral laws." In many sources, the existence of $\pi$ ó $\tau$ pror vónor are accepted as a given. In other sources such as the works of Cicero and Paul, they are critically reflected upon, while in Philo the correctness of the Jewish ancestral laws is even reinforced. Regardless of this large variation in the degree of appreciation, it is beyond doubt that the status and authority of such laws are related to their ancestral origins. What I suggest is that these other examples show that Paul also considered the ancestral law, in his case the Mosaic law, authoritative, although in his Christian phase this was not to the same degree as earlier. The fact that he regarded the Mosaic law as authoritative does not necessarily imply that he regarded the Mosaic law and the other Jewish writings as divinely revealed in their entirety. As we will see in section two, in Paul's view the Jewish writings did contain divine oracles, but he attributed the authorship of the Law as such to human authors. However, before entering this discussion, I will conclude my review of the formulas Paul used to refer to the Jewish writings.

\subsection{The Phrase "That Which Is Written Says"}

Paul not only explicitly refers to figures such as Moses, David and Isaiah - with respect to their authorship of parts of the Jewish writings-

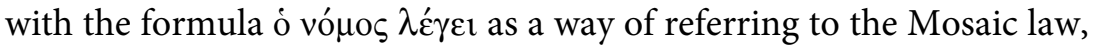

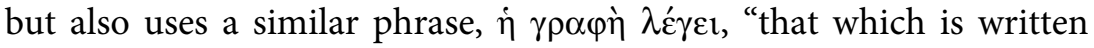
says" or, in a "Biblicizing" translation, "Scripture says." Paul uses the phrase five times and on three occasions to introduce a quotation of the Mosaic law. ${ }^{15}$ In these instances the formulas $\dot{\eta} \gamma \rho \alpha \varphi \grave{\eta} \lambda \dot{\varepsilon} \gamma \varepsilon \mathrm{r}$ and

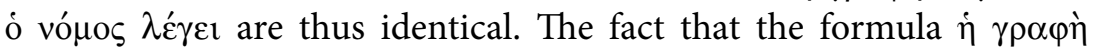
$\lambda \varepsilon^{\prime} \gamma \varepsilon t$ is mostly used to refer to the Mosaic law seems to reflect the fact that within the Septuagint reference is also made to the Mosaic law

${ }^{15}$ Gal 4:30: Gen 21:10; Rom 4:3: Gen 15:6; Rom 9:17: Exod 9:16. 


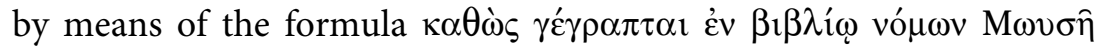

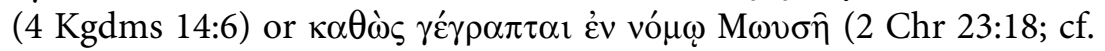

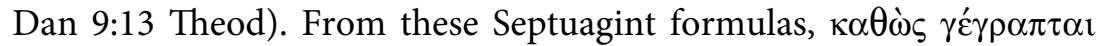
etc., it is but a small step to the formula $\dot{\eta} \gamma \rho \alpha \varphi \grave{\eta} \lambda \hat{\varepsilon}^{\prime} \gamma \varepsilon$ as an equivalent of the phrase ó vó $\mu$ os $\lambda \varepsilon^{\prime} \gamma \varepsilon$.

In two instances, however, Paul also uses the phrase $\dot{\eta} \gamma \rho \alpha \varphi \grave{\eta} \lambda \varepsilon_{\varepsilon} \gamma \varepsilon \mathrm{l}$ to refer to non-Mosaic writings: in Rom 10:11 the formula introduces a quotation from Isa 28:16 and in Rom 11:2 a quote from 1 Sam 12:11 (or Ps 94:14). These two instances are puzzling insofar as the singu-

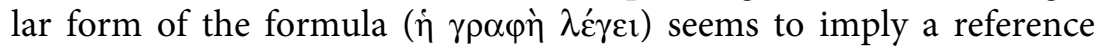
to a unified, coherent body of texts, an impression we otherwise only obtain from Paul when he speaks of "the Law and the Prophets": (Rom 3:21). I will return to this latter phrase shortly, however, it should first be mentioned that the phrase $\dot{\eta} \gamma \rho \alpha \varphi \grave{\eta} \lambda \varepsilon^{\prime} \gamma \varepsilon \mathrm{l}$ has been used in the singular in pagan Greek as a reference to a particular writing. Nevertheless, it is extremely rare and only found in the surviving documents of the fifth-century B.C.E. Greek orator Antiphon (Antiphon,

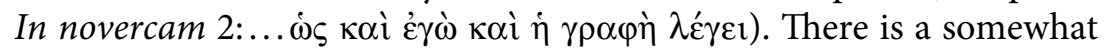
similar instance in 4 Macc. 18:14, in which the mother of the martyrs tells her sons that their father "used to remind you of the Scripture of Isaiah, which says ( pass through the fire, it shall not burn you." However, although $\gamma \rho \alpha \varphi \eta$ does occur here in the singular, it is qualified by a reference to the author, Isaiah, so that the reference is to a particular writing and not to a collective body of writings, as seems to be the case in Rom 10:11 and 11:2. There are also instances, both in pagan and Jewish sources, in which writings are referred to in the plural. Thales

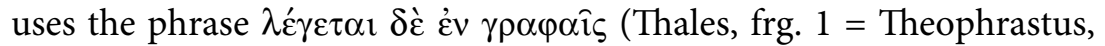

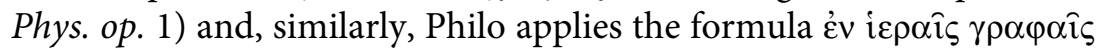
$\lambda \varepsilon^{\prime} \gamma \varepsilon \tau \alpha$ (Her. 159). However, what is strange about the two occurrences of the formula $\dot{\eta} \gamma \rho \alpha \varphi \eta े ~ \lambda \varepsilon ́ \gamma \varepsilon$ in Rom 10:11, 11:2 is, as already mentioned, that it seems to assume that Paul was already able to refer to a unified body of Jewish literature known as "the Scripture." While the plural, "the Scriptures," which he uses on various occasions (Rom 1:2; 15:4; 16:26; 1 Cor 15:3, 4), expresses the fact that the Jewish writings were written by various authors, a single reference to "the Scripture" as the common denominator of the writings of the Mosaic law, Isa and 1 Sam (and/or the Pss), quotations of which Paul introduces by means of the formula $\dot{\eta} \gamma \rho \alpha \varphi \grave{\eta} \lambda \dot{\varepsilon} \gamma \varepsilon 1$, seems peculiar and calls for an explanation. 
This oddity is not apparent with regard to the many occurrences

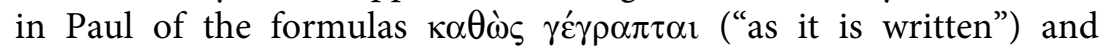
$\gamma \varepsilon ́ \gamma \rho \alpha \pi \tau \alpha_{l} \gamma \grave{\alpha} \rho$ ("for it is written"), because they are a vague way of referring to something which has been written without implying that this must be in a coherent body of texts. ${ }^{16}$ The phrase $\dot{\eta} \gamma \rho \alpha \varphi \eta \bar{\lambda} \lambda \dot{\varepsilon} \gamma \varepsilon 1$ ("the Scripture says"), however, is different in this respect and it might indeed be best understood, as I already briefly suggested above, as a unifying reference to what he has in mind elsewhere when he, if only once in his extant letters, refers to "the Law and the Prophets" (Rom 3:21). Paul speaks of "the Law and the Prophets" in the same manner as Jewish-Greek writings, as is shown in 2 Macc 15:9, Sir Prologue, 4 Macc. 18:10 and Josephus, A.J. 9.281. Yet, this characterization of the authoritative Jewish writings does not necessarily imply that they were seen as divinely revealed in their entirety. The Law, as we have seen, is the ancestral law of Moses, in the same way that pagan Greeks would talk of their ancestral laws. Other Jewish writings, as Ben Sira has shown us, were equally regarded as ancestral writings first and foremost. As we will now see, the writings of the prophets were not regarded as being fully divinely revealed. According to both Paul and Philo, the divine revelation was most tangible in the oracular statements of God himself, which were contained in these prophetic writings. These writings and God's oracles, in Philo's and Paul's shared opinion, did not coincide, leaving room for a subtle understanding of the Jewish authoritative writings. In the following section we will explore the oracular authority of the Jewish writings before moving to a discussion of the difference between oracular and prophetic authority in the fourth section.

\section{Divine, Oracular Authority: God's Oracular Utterances}

Thus, it seems that part of the authority of the Jewish Scriptures rests on their ancestral status. Paul's reference to Moses, David and Isaiah

16 The phrase $\kappa \alpha \theta \dot{\omega} \zeta \gamma^{\prime} \gamma \rho \alpha \pi \tau \alpha$, which occurs frequently in Paul (see Rom 1:17; $2: 24 ; 3: 4 ; 3: 10 ; 4: 17 ; 8: 36 ; 9: 13 ; 9: 33 ; 10: 15 ; 11: 8 ; 11: 26 ; 15: 3 ; 15: 9 ; 15: 21 ; 1$ Cor 1:31; $2: 9 ; 2$ Cor $8: 15 ; 9: 9$ ), is only found in Jewish and Christian writings and not in pagan Greek literature. For the Jewish writings, see the Septuagint: $4 \mathrm{Kgdms} \mathrm{14:6;} \mathrm{23:21;}$

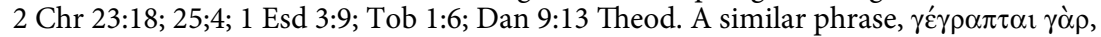
which also occurs in Paul (Rom 12:19; 14:11; 1 Cor 1:19; 3:19; Gal 3:10; 4:22; 4:27), is also found in pagan Greek writings. See, e.g., Demosthenes, Aristocr. 24. There are many occurrences of this phrase in the writings of Galen. 
as the authors of the writings he quotes implies that these writings are thought to be authored by humans. Furthermore, the formula "the Law says," which Paul uses, is primarily a reference to an authoritative ancestral law. Even the formula "that which is written says," which is either equivalent to the formula "the Law says" or synonymous with a reference to "the Law and the Prophets," does not suggest the "Scripture" referred to is divine in origin. All these references and formulas seem to touch mainly upon the ancestral authority of the Jewish writings. This seems to be all the more the case as, in addition to these instances of ancestral authority, Paul explicitly states when God is the actual author of a specific passage in the Jewish writings. These passages are those where God is quoted as the subject of direct divine speech. There are many instances in which Paul qualifies specific quotations from the Jewish Scriptures as divine by means of the phrase

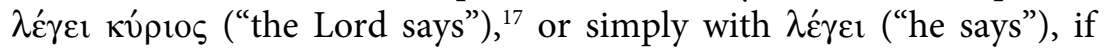
it is sufficiently clear that God is the subject of the utterance. ${ }^{18}$ Sometimes the phrase $\lambda \varepsilon^{\prime} \gamma \varepsilon 1$ кúptos is part of the original quotation and does not have to be supplemented by Paul with an introductory formula. ${ }^{19}$ What is remarkable in all these cases is that without exception the quotations concern utterances by God in direct speech. The formula is never followed by descriptive indirect speech.

In two instances Paul explicitly describes this direct divine speech as being addressed to a human author, or as being reported in the writings of such an author. In the first instance Paul writes:

What then are we to say? Is there injustice on God's part? By no means!

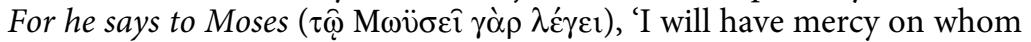
I have mercy, and I will have compassion on whom I have compassion' (Exod 33:19). So it depends not on human will or exertion, but on God who shows mercy. (Rom 9:14-16)

This example clearly shows that God is quoted in direct speech and that this divine utterance is addressed to Moses, who subsequently noted it down in Exodus.

${ }_{17}$ In 1 Cor 14:21 Paul quotes the divine speech of Isa 28:11-12. See further Rom 12:19: Deut 32:35.

${ }_{18}^{18}$ See 2 Cor 6:2: Isa 49:8; Gal 3:16: Gen 13:15; 17:8; $24: 7$.

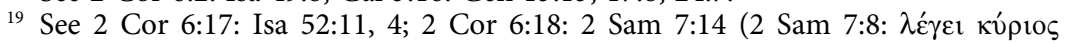
$\pi \alpha v \tau$ окр́́ $\tau \omega \rho)$; Rom 14:11: Isa 49:18; Jer 22:24, Ezek 5:11 etc.; Isa 45:23. 
In the second instance Paul describes how a divine utterance was recorded in the book of Hosea. Paul, reflecting on God's wrath and mercy, writes:

What if God, desiring to show his wrath and to make known his power, has endured with much patience the objects of wrath that are made for destruction; and what if he has done so in order to make known the riches of his glory for the objects of mercy, which he has prepared beforehand for glory-including us whom he has called, not from the Jews only but

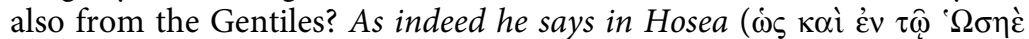
$\left.\lambda \varepsilon^{\prime} \gamma \varepsilon 1\right)$, "Those who were not my people I will call "my people", and her who was not beloved I will call "beloved"' (Hos 2:25). "And in the very place where it was said to them, "You are not my people," there they shall be called children of the living God' (Hos 2:1). (Rom 9:22-26)

Again, God's utterances are in direct speech and they are said to be recorded in the book of Hosea. Apparently, divine speech does not fully coincide with the writings of Hosea or Moses, but is contained in them in those words which God uttered in first person direct speech. This also applies to all of the examples mentioned above where Paul quotes God's own words, introduced by the formula $\lambda \varepsilon \dot{\varepsilon \varepsilon \imath ~ \kappa u ́ p ı s ~}$ or simply $\lambda \varepsilon^{\prime} \gamma \varepsilon$. All these examples contain divine sayings in direct speech.

That Paul takes only these words to be divine utterances is explicitly confirmed in Rom 11:3-4 where Paul depicts them as oracular utterances. Paul does so by distinguishing between, on the one hand, the question posed to God by Elijah concerning his loneliness, as narrated in $1 \mathrm{Kgs} 19$ ("the Scripture"), and God's reply to Elijah on the other hand. As we will see, this divine reply is explicitly described as oracular. The dialogue between Elijah and God is relevant to Paul in the context of his considerations of whether God has rejected the Jewish people. According to Paul:

God has not rejected his people whom he foreknew. Do you not know

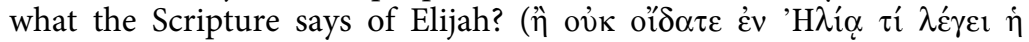
$\gamma \rho \alpha \varphi \eta$;) How he pleads with God against Israel: 'Lord, they have killed your prophets, they have demolished your altars; I alone am left, and they are seeking my life' (1 Kgs 19:10-14). But what is the divine reply to

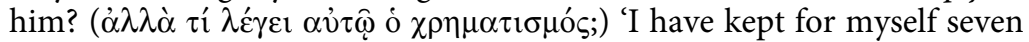
thousand who have not bowed the knee to Baal' (1 Kgs 19:18). So too at the present time there is a remnant, chosen by grace. (Rom 11:2-4)

This passage shows that "the Scripture" ( $\dot{\eta} \gamma \rho \alpha \varphi \eta$ ) has no particular divine qualities in itself. Rather it is seen as a correct historical 
description of events, in this case the history of Elijah, whose desolate question to God is reported here. It is God's verbatim reply, however, again in first person direct speech, which is regarded as divine-as a $\chi \rho \eta \mu \alpha \tau \imath \sigma \mu o ́ s$, a divine, oracular response. ${ }^{20}$ Hence, the Scripture is authoritative not because it is itself divine but because it contains divine oracles to which it provides a proper historical setting and on which it is assumed to reflect.

Paul's use of $\chi \rho \eta \mu \alpha \tau \imath \sigma \mu o ́ s$ is fully paralleled by the retelling in 2 Macc of an episode in Jeremiah's life following the destruction of the temple in Jerusalem, which is unknown from the book of Jeremiah itself (2 Macc 2:1-8). The author of 2 Macc introduces this passage with the claim that he found this information "in the records" (2 Macc 2:1). After disclosing some information from these records, the author of 2 Macc continues:

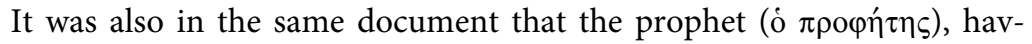
ing received an oracle $(\chi \rho \eta \mu \alpha \tau \iota \sigma \mu о \hat{v} \gamma \varepsilon v \eta \theta \varepsilon \dot{\varepsilon} \tau o \varsigma)$, ordered that the tent and the ark should follow with him, and that he went out to the mountain where Moses had gone up and had seen the inheritance of God. Jeremiah came and found a cave-dwelling, and he brought there the tent and the ark and the alter of incense; then he sealed up the entrance. (2 Macc 2:4-5)

According to this passage, the records reveal that the prophet Jeremiah received a particular divine oracle concerning the storage of the tent and the ark following the temple's destruction. The link which the author of 2 Macc establishes between being a prophet and receiving an oracle is particularly relevant. Jeremiah, who is known as the author of the book of Jeremiah, is a prophet not because he wrote a book but because he received oracles. In line with this, one could argue that a prophetic book is not of divine quality but does contain oracles in direct speech from God. This is certainly also the picture which arises from the example of Rom 11:2-4, in which neither the narrative of $1 \mathrm{Kgs} 19$ nor the entire book of $1 \mathrm{Kgs}$ is seen as divine. This is reserved only for God's oracular response.

We see something similar in Prov 31:1, which reads:

\footnotetext{
20 The translation "divine reply" (NRSV) conceals the oracular nature of a

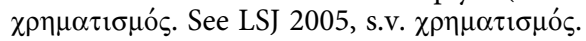




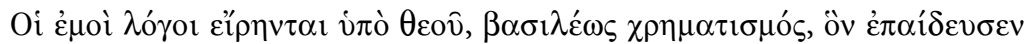
$\dot{\eta} \mu \dot{\eta} \tau \eta \rho \alpha \hat{\tau} \tau$ ov (My words have been spoken by God, an oracle of the king, which his mother taught him)

The words which God has spoken are characterized as an oracle, in this case transmitted by the king's mother to her son. Other examples containing the closely related terminology of $\chi \rho \eta \sigma \mu$ ó ("oracular response, oracle") occur in Philo and will be discussed later in connection with the differentiation between oracular and prophetic authority (see section four below).

This terminology of divine oracles, $\chi \rho \eta \mu \alpha \tau \imath \sigma \mu o i ́$, is also known in pagan Greek. Vettius Valens, for example, speaks of $\theta \varepsilon \hat{\omega} v \chi \rho \eta \mu \alpha \tau \imath \sigma \mu o ́ s$, "oracles of the gods," at the beginning of his work (Anth. 1.1). Moreover the link between prophets and oracles as present in 2 Macc 2:4-5 is also attested to by several pagan Greek authors, such as Demon, Diodorus Siculus and Polyaenus. ${ }^{21} \mathrm{~A}$ very relevant passage is also found in Josephus, who uses the same terminology in a retelling of the episode of Isaiah's prediction of the Assyrian retreat in 2 Kgs 18:37. Josephus writes:

When the prophet had done these things and received an oracle from

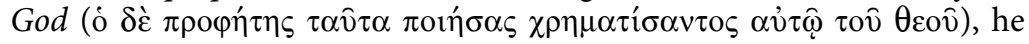
encouraged both the king himself and the friends who were with him by foretelling that the enemy would be defeated without a battle and retire ignominiously. (A.J. 10.13)

This close link between prophecy and oracles is in line with the pagan Greek understanding of a prophet, which is defined by Robert Parker as "the mortal who speaks in the name of a god or interprets his will. It is properly used only of seers and functionaries attached to an established oracular shrine." 22 It also confirms what we have surmised above. The book of the prophet Isaiah contains oracles of God which Isaiah, as a prophet, received and apparently subsequently included in his book. For that reason, one might say that the prophetic book is not in itself divine but does contain divine oracles. This also seems to be Paul's view. If it is God's oracular words that are divine, it follows that prophetic writings as such are not regarded as divine. Rather

${ }^{21}$ Demon, Fragmenta 10; Diod. Sic. 14.13.3; Polyaenus, Strategemata 1.16.1.

22 R.C.T. Parker, "Prophētēs," in The Oxford Classical Dictionary (ed. S. Hornblower and A. Spawforth; 3d ed.; Oxford: Oxford University Press, 1996), 1259. 
they have distinct authors such as Moses, David, Isaiah and the author of $1 \mathrm{Kgs}$.

Paul's use of oracular terminology is not restricted to Rom 11:3-4 but also occurs in Rom 3:2 when he states that "in the first place the

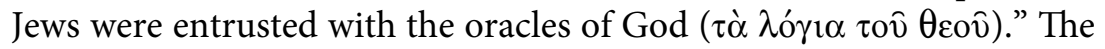
combination of $\lambda$ ó $\gamma 1 \alpha$ and $\chi \rho \eta \sigma \mu$ oí often occurs in Greek sources, for example, in Dionysius Halicarnassensis who speaks of $\Sigma_{1} \beta \hat{u}^{\prime} \lambda \lambda \eta \varsigma \tau \varepsilon$

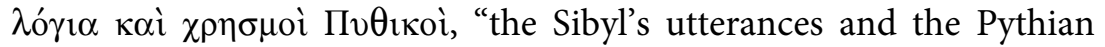
oracles" (Ant. rom. 1.49.3) ${ }^{23}$ Another noteworthy occurrence is also found in Eusebius, according to whom:

The oracles of the Hebrews containing prophecies and responses of

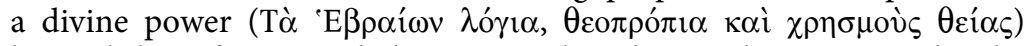
beyond that of man, and claiming God as their author... are said to be free from all erroneous thought. (Praep. ev. 13.14.1)

The terms $\lambda$ ó $\gamma 1 \alpha$ and $\chi \rho \eta \sigma \mu o i ́$ are often found together and Paul also employs both oracular terms. It seems that Paul's conscious reference to passages in the Jewish writings which are attributed to God's direct speech and his use of oracular terminology show that he not only attributed ancestral authority to the Jewish writings but also acknowledged that some parts of them were invested with divine oracular authority.

\section{Prophetic Authority vis-à-vis Oracular Authority: Philo's View}

As we have seen, within the Jewish Scriptures Paul attributes the highest authority to God's oracular responses. At the same time, and as the beginning of his letter to the Romans makes clear, Paul speaks of prophets $(\pi \rho \circ \varphi \eta \tau \alpha \imath)$ as the authors of $\gamma \rho \alpha \varphi \alpha i$ ö $\gamma 1 \alpha \mathrm{l}$, "holy writings":

Paul, a servant of Jesus Christ, called to be an apostle, set apart for the gospel of God, which he promised beforehand through the prophets in holy writings. (Rom 1:1-2)

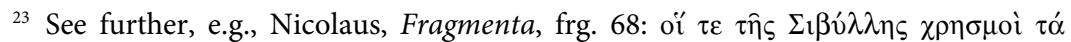

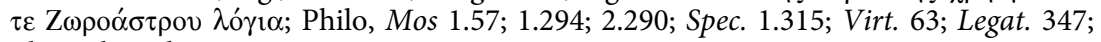
Plutarch, Pel. 20.7; Lys. 25.2; Arist. 15.4. 
The question of what the precise difference is between prophets and holy writings, on the one hand, and divine oracular responses and oracles on the other, now arises. How does the oracular authority of particular parts of the writings relate to the authority of the prophets who authored the entire writings of which the oracles have become part? It appears that this question is fully reflected upon by Philo, who, as we will see, shares the same oracular vocabulary of Paul. By way of introduction I will briefly refer to Helmut Burkhardt's 1988 monograph on Philo's view on the divine inspiration of the holy writings, and will first summarize three important observations which are relevant for the present enquiry.

Firstly, Burkhardt draws attention to the fact that Philo used a varied and rich vocabulary to refer to the Jewish Scriptures. Each term points to a particular aspect of these writings:

Während die Begriffe graphè, grammata und anagraphai mehr die äussere Gestalt der Aufzeichnung ansprachen, bibloi und stèlai das Material, nomos und nomothesia den Inhalt, hieros logos aber als Terminus der Mysterienkulte auf den gottesdienstlichen Gebrauch verwies, so berühren die... Ausdrücke chrèsmos und logion die Frage der Herkunft, nämlich aus göttlicher Offenbarung. Beide Begriffe sind in der antiken griechischen Mantik beheimatet. ${ }^{24}$

Among these terms and phrases we find the oracular vocabulary of chrèsmoi and logia.

Secondly, although these chrèsmoi and logia are now fully integrated into the Jewish Scriptures, according to Burkhardt, the implication is that prior to their inclusion the oracles existed separately and were embedded in history before they were incorporated into a written corpus. The Jewish writings as we know them, according to Philo, often present these oracles within a narrative and interpretive context. As Burkhardt phrases it, these oracles are "an oder auch durch Menschen der Bibel ergangene Gottesworte: an Kain, an Noah, an Abraham, an Sarah, an Isaak, an Jakob, an Mose, durch Mose, an Bileam, durch Bileam":

Zwar handelt es sich hier faktisch überall um Worte der Bibel, die Philo hier aber jeweil nicht als solche anführt, sondern unabhängig von ihrer

\footnotetext{
${ }^{24}$ H. Burkhardt, Die Inspiration heiliger Schriften bei Philo von Alexandrien (Giessen: Brunnen, 1988), 111.
} 
späteren Integration in die biblischen Schriften als vereinzelte, in der Geschichte, die er beschreibt, ergangene Gottesworte. ${ }^{25}$

There is, thus, a small, but not unimportant difference between the actual oracles and the secondary form in which they are incorporated into the "biblical writings."

Thirdly, as Burkhardt rightly points out, despite the variety of these oracles, and notwithstanding the fact that it is possible to differentiate them from the writings in which they are contained, the importance of the concept of oracles renders the term "oracles" a designation for the collective corpus of Jewish writings. The plural "oracles" is used as a designation for the biblical writings in toto. However, even then the term reminds the reader of the original separate oracles that were spoken at specific moments in history, before being collected in the Jewish Scriptures. Although "oracles" functions as a "Name für die Gesamtheit der biblischen Schriften," the following remains true:

Dabei halt allerdings eben diese Pluralform stets das Bewusstsein daran wach, das chrèsmos an sich das Einzelorakel ist, also eine in der Regel kleine Einheit von einem oder wenig mehr Versen. Der Name hoi chrèsmoi für die biblischen Schriften bezeichnet diese also als eine Orakelsammlung. ${ }^{26}$

I will firstly give an example which demonstrates that hoi chrèsmoi is a title for the Jewish Scriptures in their entirety, before touching upon the variety of particular oracles which are embedded in these Scriptures. That the reference to "the oracles" may be a reference to the collection of all Jewish Scriptures is, for example, clear from the following passage, in which Philo reflects upon the application of the allegorical method to the Jewish writings:

So we must turn to allegory, the method dear to men with their eyes opened. Indeed the oracles (oi $\chi \rho \eta \sigma \mu o i)$ most evidently afford us the clues for the use of this method. For they say that...(Plant. 36)

Here the term "oracles" clearly stands for the collective Jewish writings.

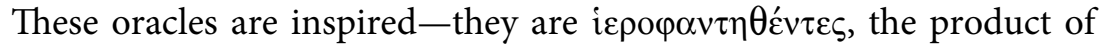
initiation and instruction in mysteries (Deus 62; Somn. 1.207). They

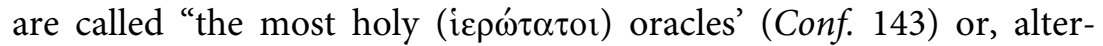

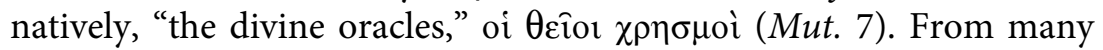

${ }^{25}$ Burkhardt, Die Inspiration heiliger Schriften, 114.

${ }^{26}$ Burkhardt, Die Inspiration heiliger Schriften, 118. 
passages it appears that these "collective oracles" are the sum total of distinct oracles.

The original separate oracles which had not yet been included in collective writings were characterized and specified in the following ways. These oracles are often (although not always) expressed in direct divine speech, as in the following case:

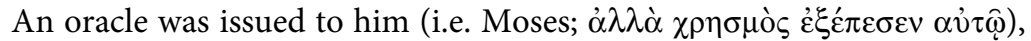
'Thou shalt behold that which is behind Me, but My face thou shalt not see' (Exod 33:23) (Post. 169).

According to Philo, oracles are a separate source of information, in addition to the sources of philosophy and history. Moses, for example, is described as someone who not only had access to philosophy but also to oracles. Moses' knowledge is understood to be based on this dual expertise:

Moses, both because he had attained the very summit of philosophy, and because he had been instructed through oracles ( $\chi \rho \eta \sigma \mu \circ \hat{\varsigma} \varsigma)$ in the greater and most essential part of Nature's lore, could not fail to recognize that... (Opif. 8). ${ }^{27}$

Likewise, oracles offer historical information which is not otherwise available. As Philo says, in this way Moses learnt of the pre-historic times of creation:

Let not us then, the pupils of Moses, be any longer at a loss as to how man came to have a conception of the invisible God. For Moses himself learnt it by an oracle $\left(\chi \rho \eta \sigma \mu(\omega)\right.$, and has taught us how it was $(\text { Det. } 86)^{28}$

${ }^{27}$ Cf. also Fug. 55-56: "I attended the lectures of a wise woman, whose name is Consideration... She confirmed what she said by oracles also ( $\chi \rho \eta \sigma \mu o i \varsigma)$ ); Mos. 1.207: "Long before, they had asked what was the birthday of the world on which this universe was completed, and to this question... they now at long last found the answer, learnt not only through oracles ( $\chi \rho \eta \sigma \mu o \hat{\varsigma} \varsigma)$ but by a perfectly certain proof."

${ }^{28}$ Josephus also emphasizes the divine inspiration which enabled Moses to write the history of the period prior to him. He also seems to regard the (post-Mosaic) prophets as reporters of the history of their day. According to Josephus, the prophets, among whom he includes Moses, obtained "their knowledge of the most remote

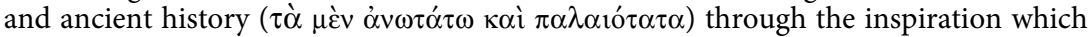

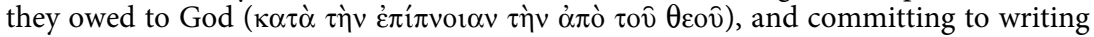
a clear account of the events of their own time just as they occurred.... Our books, those which are justly accredited, are but two and twenty, and contain the record of all time. Of these, five are the books of Moses, comprising the laws and the traditional

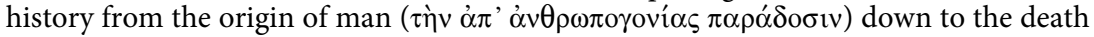
of the lawgiver.... From the death of Moses until Artaxerxes, who succeeded Xerxes as king of Persia, the prophets subsequent to Moses wrote the history of the events of 
In these passages, the "oracles" clearly refer to specific moments in time, before they were collected, put into written form and embedded in a narrative context. In the same way, "the oracles" can also be the specific ten commandments given by God to Moses (Migr. 85).

In addition to these and other oracles there are also specific oracles, such as the following "Messianic" oracle which resembles a similar prophecy in Josephus and probably derives from Balaam's oracle in Num 24:7 LXx: $:^{29}$

For 'there shall come forth a man', says the oracle ( $\varphi \eta \sigma i v$ ò $\chi \rho \eta \sigma \mu o ́ s)$, and leading his host to war he will subdue great and populous nations, because God has sent to his aid the reinforcement which befits the godly, and that is dauntless courage of soul and all-powerful strength of body. (Praem. 95)

If looked upon in detail, it is Philo's view that the Jewish writings are a collection of specific, distinct oracles, each given in particular historical circumstances. As we have already seen, together, as a collection placed in the narrative and interpretative setting of the Jewish Scriptures, they can also be referred to as "the oracles."

The specific relationship between the individual oracles and the prophets who receive, interpret and collect them, is examined in detail in a particular passage in Philo's De vita Mosis, in which much of what I have argued in this paper is also discussed. As we will see, the vocabulary of this passage is almost identical to that used by Paul. Here Philo distinguishes between three different types of oracles. I will first mention them before quoting the passage in full. Subsequently, I will provide a detailed commentary on the entire passage.

According to Philo, three types of oracles are to be distinguished: (1) oracles which are spoken by God "in his own person" in direct divine speech and which are simply noted down by the prophets, who, in these instances, merely act as translators and intermediaries of the divine will; (2) oracles which are part of a more elaborate set of questions and divine answers brought about in a kind of interplay and cooperative relationship between prophet and God; (3) and, finally,

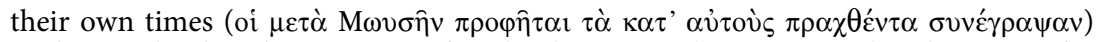
in thirteen books. The remaining four books contain hymns to God and precepts for the conduct of human life" (C. Ap. 1.37-40).

${ }^{29}$ See further Tacitus, Hist. 5.13; Suetonius, Vesp. 4.5. 
oracles which are not spoken by God but by the prophet, although under divine influence.

This concise distinction shows that prophetic authority and divine oracular authority are not simply one and the same. The third kind of oracle in particular shows a greater independence of the prophet vis-à-vis God than the first kind. In Philo's view, it is the third kind of oracle which is more appropriately viewed as Moses' own. Although he is inspired when he utters them, it is Moses' prophetic capacity which is evident, rather than God's inspiration. This shows that the Jewish Scriptures were not yet categorically understood as the simple product of divine revelation, but were seen to exhibit various degrees of revelation mingled into a single collection of writings.

In the introductory passage from his De vita Mosis, Philo offers a sketch of the three different kinds of oracles:

...I will now go on to show in conclusion that he (i.e. Moses) was a prophet of the highest quality. Now I am fully aware that all things written in the sacred books are oracles delivered through Moses. But I will confine myself to those which are more especially his, with the following preliminary remarks. Of the divine utterances, (1) some are spoken by God in His own Person with His prophet for interpreter, (2) in some the revelation comes through question and answer ( $\tau \dot{\alpha} \delta$ '

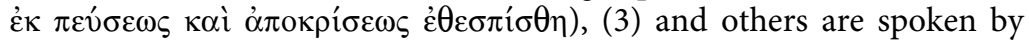
Moses in his own person, when possessed by God and carried away out of himself. (1) The first kind are absolutely and entirely signs of divine excellences, graciousness and beneficence, by which $\mathrm{He}$ incites all men to noble conduct....(2) In the second kind we find combination and partnership: the prophet asks questions of God about matters on which he has been seeking knowledge, and God replies and instructs him. (3) The third kind are assigned to the lawgiver himself: God has given to him of His own power of foreknowledge and by this he will reveal future events. (1) Now, the first kind must be left out of the discussion. They are too great to be lauded by human lips.... Besides, they are delivered through an interpreter, and interpretation and prophecy are not the same thing. (2) The second kind I will at once proceed to described, interweaving with it (3) the third kind, in which the speaker appears under that divine possession in virtue of which he is chiefly and in the strict sense considered a prophet. (Mos. 2.187-191)

A treatment of the oracles of mixed character then follows (2.192-245), after which Philo, with reference to the introductory passage quoted above, introduces the third kind of oracle:

Having completed this necessary account of the oracles of mixed character, I will proceed next to describe those delivered by the prophet himself 


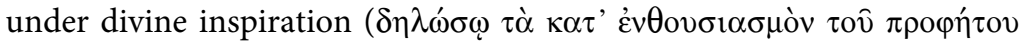
$\theta \varepsilon \sigma \pi \imath \sigma \theta \dot{\varepsilon} v \tau \alpha \lambda \operatorname{oo}_{1} \alpha$ ), for this was included in my promise. (Mos. 2.246).

After this treatment (2.246-287), there are a few remarks about the final passages of the Mosaic writings (2.288-292), where Moses, just before his death, is said to utter some oracles and inspired sayings to each individual tribe of the Israelites, as well as prophesying his own death:

Then, indeed, we find him possessed by the spirit, no longer uttering general truths to the whole nation but prophesying to each tribe in particular the things which were to be and hereafter must come to pass.... It was very fitting that persons so different... should receive as a sort of legacy a suitable apportionment of oracles and inspired sayings

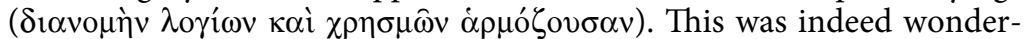
ful. But most wonderful of all is the conclusion of the holy Scriptures

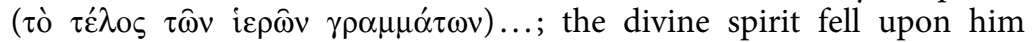
and he prophesied with discernment while still alive the story of his

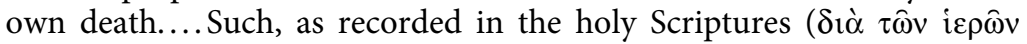

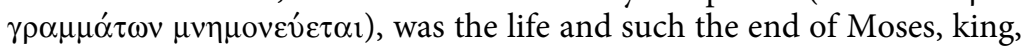
lawgiver, high priest, prophet. (Mos. 2.288-292)

The passages above outline the last part of Philo's second treatise on the life of Moses. While the first treatise discusses Moses as king, the second treatise treats Moses in his capacity as lawgiver, high priest and prophet. It is the last aspect, that of Moses as prophet which concerns us here, and the passages just quoted constitute the framework of Philo's discussion. This framework yields a number of interesting points, which I will comment on below. Firstly, however, I will provide some remarks on Philo's general views about the relationship between the sacred books and the oracles, before discussing the three specific kinds of oracles which he distinguishes in more detail.

\subsection{Sacred Books and Oracles: Some General Remarks}

Firstly, Philo says that "all things written in the sacred books are ora-

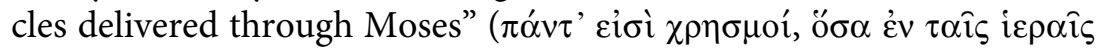

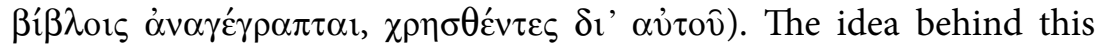
passage is that sacred books contain oracles. This implies that sacred books are constituted by more than their oracular content. Such an idea is confirmed by the following passage from Philo's De migratione Abrahami, in which Philo discusses the appropriateness of the title of the second book of the Mosaic Pentateuch and mentions that oracles are contained in this book: 
Right well, then, did the Hierophant (the one who teaches rites of sacrifice and worship, i.e. Moses) inscribe one entire sacred book of the law-

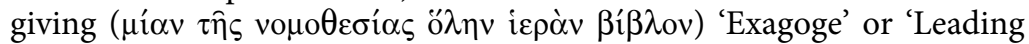
Out,' for the name thus found was appropriate to the oracles contained

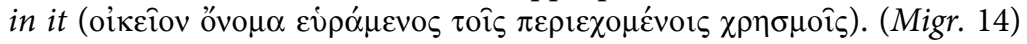

Sacred books of Mosaic lawgiving thus contain oracles. It even seems that these books are actually considered sacred because of these oracles. Therefore, sacred books are not so much sacred in their own right but derive their status from the oracles within them. In the introductory passage on Moses' status as a prophet from De vita Mosis, quoted above, the books which encompass these oracles are called $\alpha i$

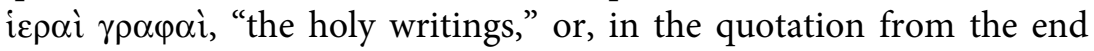

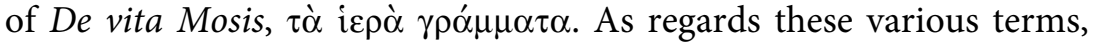

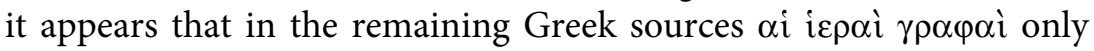

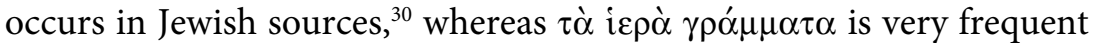
both in pagan and Jewish sources, including Plato, Diodorus Siculus, Strabo and Plutarch among the pagan, and Philo and Josephus among the Jewish authors. ${ }^{31}$ Another frequent term in pagan and Jewish writ-

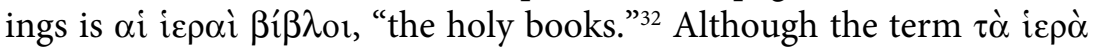

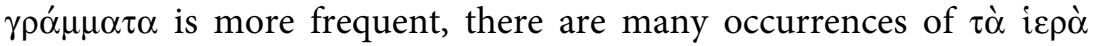
$\gamma \rho \alpha \mu \mu \alpha \tau \alpha$ which do not refer to books, but to the inscriptions of holy characters, especially Egyptian hieroglyphs on surfaces such as pillars. ${ }^{33}$

If we compare Philo's terminology to that of Paul, we find the following. According to Philo in his introduction to Moses as prophet, "all things written in the sacred books are oracles delivered through Moses." As we have seen, Paul also regards the holy writings as consist-

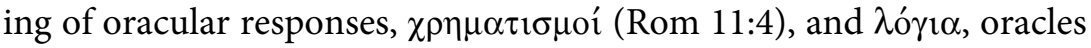
(Rom 3:2; see section one above). Similarly to Philo, at the very beginning of his letter to the Romans, Paul distinguishes between prophets and holy writings. According to Paul, God had already announced the gospel beforehand "through the prophets in holy writings" (not, as the NRSV translates: "through his prophets in the holy scriptures"):

30 The occurrence in Hecataeus of Abdera is probably due to the preservation of this text in Josephus, C. Ap. 2.45. Among other phrases, Josephus also uses the phrase

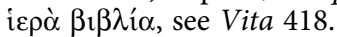

31 See the many occurrences in the Thesaurus Linguae Graecae.

32 See esp. Diod. Sic. $1.44 .4 ; 1.70 .9 ; 1.73 .4 ; 1.82 .3 ; 1.95 .5 ; 1.96 .2 ; 34 / 35.1 .4$ (7x), Philo $(27 \mathrm{x})$ and Josephus (19x). There are also occurrences in 2 Macc 8:23 and Plutarch, Num. 22.2.

${ }^{33}$ Cf. also Jan Bremmer's contribution to this volume. 


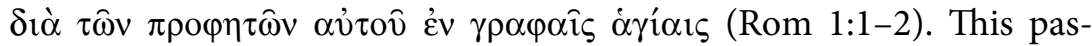
sage raises the same question about the precise relationship between prophets and their holy writings as we encounter in an explicit form in Philo's De vita Mosis.

It seems that the slight variation in terminology between Philo and

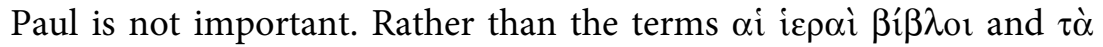

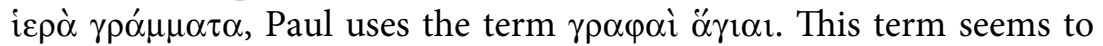
occur first in Paul. Similar expressions are used in the Testaments of the Twelve Patriarchs, specifically in the Testament of Napthali, which tells us that the dying Jacob refers to "the writing of holy Enoch" (4:1) and also mentions "a sacred writing" which appeared to him (5:8). ${ }^{34}$ However, as the Testaments of the Twelve Patriarchs seem to be Christian, Paul's use of the expression $\gamma \rho \alpha \varphi \alpha i$ ö $\gamma 1 \alpha i$ must be earlier, and even if this term constitutes a Pauline neologism there does not seem to be a conceptual or otherwise notable difference between $\gamma \rho \alpha \varphi \alpha i$ "̈ $\gamma 1 \alpha \mathrm{r}$ and Philo's terminology. Firstly, as we will see further below, in later Pauline writings the author of 2 Tim returns to the expression

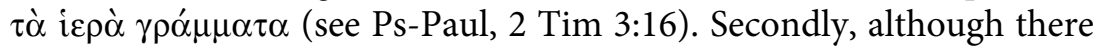
seems to be a notable difference between Paul's use of the adjective

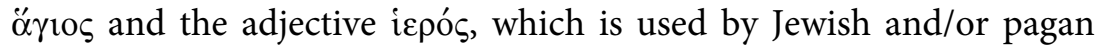

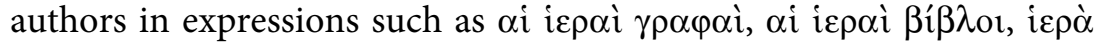

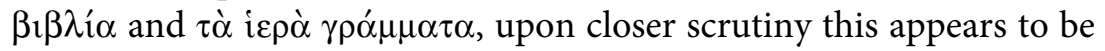
irrelevant. The Jewish author of 1 Macc also uses the adjective ö $\gamma 10 \varsigma$ to describe the authoritative Jewish writings, which he calls $\tau \grave{\alpha} \beta \beta_{1} \beta \lambda i \dot{\alpha} \tau \dot{\alpha}$ ö $\gamma 1 \alpha$, "the holy books." Here, in his letter to the Spartans, the Jewish high-priest Jonathan says that "we have as encouragement the holy books that are in our hands" (1 Macc 12:9). In a comparable way to

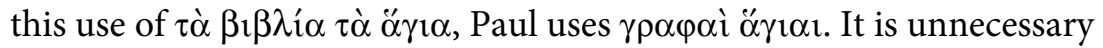
to assume that Paul feels the need to explicitly correct the terminology

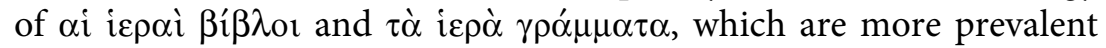
among both pagans and Jews.

If there was a difference in emphasis between Paul's characterization of the authoritative Jewish writings as $\gamma \rho \alpha \varphi \alpha i$ ö $\gamma 1 \alpha 1$ and the depictions

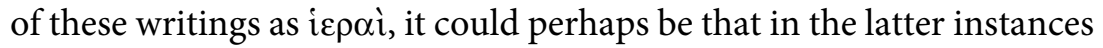
there was some sort of implicit link with tò iepòv, the temple, in which holy writings were often stored. Whereas tò öriov is only used in

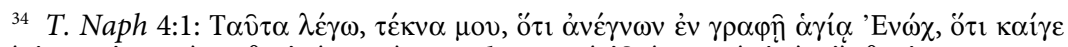

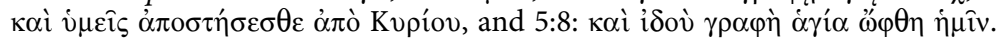


Jewish and Christian sources as a designation for the temple, $\tau$ ì iepòv is the common pagan term, which, in addition to tò ö $\gamma$ rov, is also used

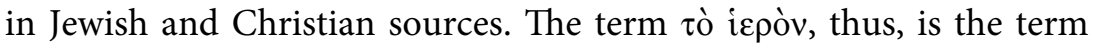
shared by pagans, Jews and Christians, and used to refer to both pagan temples and the Jewish temple in Jerusalem. The link between holy writings and $\tau$ ò iepòv, the temple, is explicitly made in several passages in Josephus. In A.J. 3.38, Josephus says that "a writing deposited in

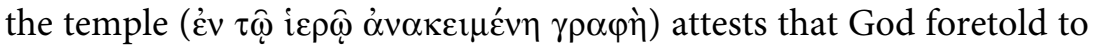
Moses that water would thus spring forth from the rock." In another passage, in A.J. 4.303-304, Josephus writes:

Then he (i.e. Moses) recited to them a poem in hexameter verse, which he has moreover bequeathed in a book preserved in the temple

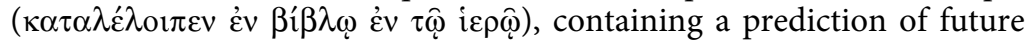
events, in accordance with which all has come and is coming to pass, the seer having in no whit strayed from the truth. All these books he con-

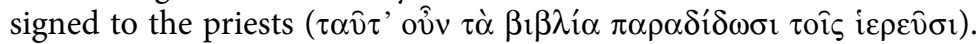

Also, on a different occasion, in order to emphasize a particular fact, Josephus claims that it "is attested by the Scriptures that are laid up in

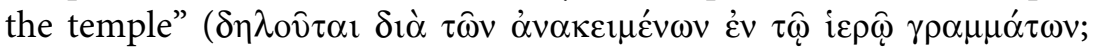

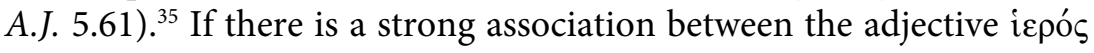
and the very frequently used term tò icpòv, this could be a reason why Paul did not want to characterize the authoritative Jewish writ-

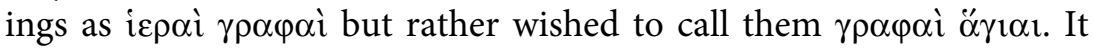
may well be that given his emphasis on the rational, non-ritual nature of Christianity (Rom 12:1-2) and his apparent disinterest in the Jewish temple, the Jewish writings for him were not holy on account of their close relationship to the temple. ${ }^{36}$ Yet, as I have pointed out, the Jewish author of 1 Macc could also opt for the adjective ö $\gamma$ ios and

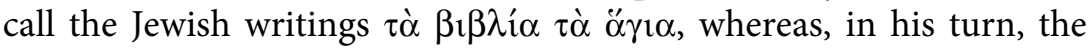

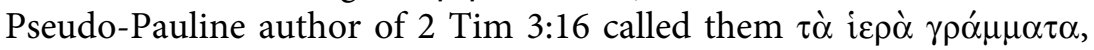
apparently not sharing Paul's possible reservations.

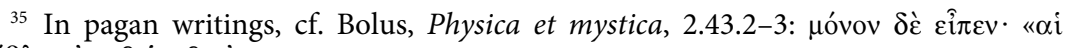

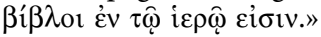

${ }^{36}$ For Paul's emphasis on the rational, non-ritual nature of Christianity and his alternative view on humanity as God's shrine, which houses God's image, see G.H. van Kooten, Paul's Anthropology in Context: The Image of God, Assimilation to God, and Tripartite Man in Ancient Judaism, Ancient Philosophy and Early Christianity (Tübingen: Mohr Siebeck, 2008).
} 
However, whatever the difference between Paul and Philo in their nomenclature for the Jewish Scriptures, whether Paul calls them $\gamma \rho \alpha \varphi \alpha i$

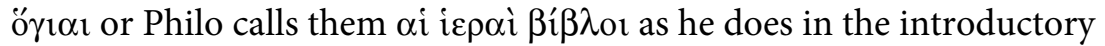
passage on Moses as prophet, both authors agree that the holy writings contain oracles. As Philo says with regard to the Mosaic Pentateuch, "all things written in the sacred books are oracles delivered through Moses." In the last instance, thus, it seems that these books are holy

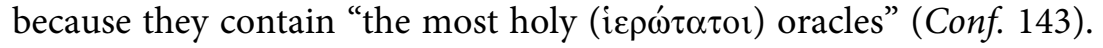

\subsection{Three Specific Kinds of Oracles}

In the extensive passage from De vita Mosis quoted above Philo distinguishes three types of oracles. The first type consists of oracles in the strictest sense of the word. As Philo states:

Of the divine utterances, some are spoken by God in His own Person

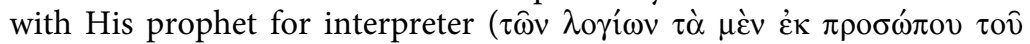

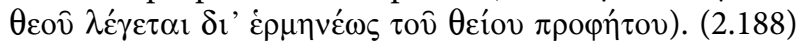

Like Paul, Philo also calls the oracles $\lambda$ óri $\alpha$ (cf. Paul in Rom 3:2). The first type, which are delivered through Moses, are those which are "spoken by God in His own Person." I will provide a brief overview of the various instances in which Philo describes these spoken oracles

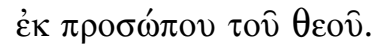

Borrowing the terminology of initiation into the greater and the lesser mysteries from the Eleusinian mysteries, Philo describes his own relationship to Moses and the prophets, and in this context refers to an oracle received by one of the prophets:

I myself was initiated under Moses the God-beloved into his greater mysteries, yet when I saw the prophet Jeremiah and knew him to be not only himself enlightened, but a worthy minister of the holy secrets

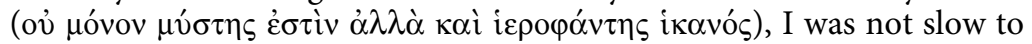
become his disciple. He (i.e. Jeremiah) out of his manifold inspiration gave forth an oracle spoken in the person of God (o $\delta$ ' $\alpha^{\prime} \tau \tau \dot{\alpha} \pi \mathrm{o} \lambda \lambda \dot{\alpha}$

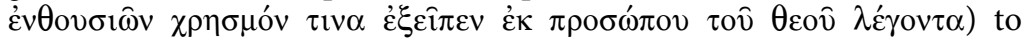
Virtue the all-peaceful: 'Didst thou not call upon Me as thy house, thy father and the husband of thy virginity?' (Jer 3:4) (Cher. 49)

Philo's interpretation of this oracle follows, but what concerns us here is that Philo describes his access to God's oracles as an initiation into the mysteries in which Moses and the prophets act like the initiating priest at Eleusis, passively receive the oracles of God, which are 
"spoken in the person of God," and subsequently teach the pupil who is to be initiated. The example from Jeremiah 3:4 also clearly shows, as we have seen before, that Philo does indeed distinguish between the oracles, in this case "an oracle spoken in the person of God," and the fuller narrative and interpretative context of the book of Jeremiah.

Similar examples of oracles spoken by God in his own person can be drawn from other treatises in which it is explicitly stated that particular oracles are spoken by God (see Plant. 63; Mut. 39; Somn. 2.221; Spec. 4.39). All these examples concern oracles which are given in direct divine speech. As a matter of fact, they are fully comparable with the passages from Paul which were discussed in section one above and in which Paul introduces utterances of God in direct speech by means of such phrases as $\lambda \dot{\varepsilon} \gamma \varepsilon ı$ kv́pıs. As we saw above, Philo, in his formal, "technical" analysis of the various kinds of oracles contained in the Jewish Scriptures, calls them oracles which are spoken by "God in His own Person."

In one particular passage Philo gives an impression of how he believes this kind of oracle is transmitted by God in direct divine speech to the prophet who receives it:

I remember too an oracle given by a prophet's mouth in words of fire

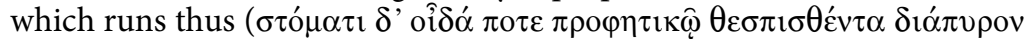

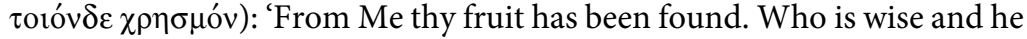
shall understand them, who is understanding and he shall know them?' (Hos 14:9-10). Under the prophet's words I recognized the voice of the invisible Master whose invisible hand plays on the instrument of human speech, and I was lost in admiration at the saying also. (Mut. 139)

As this passage implies, the degree to which the prophet participates in this kind of oracle is minimal, their role being only instrumental. In this case, as Philo explains in the extensive passage from the $D e$ vita Mosis, the prophet is actually only an intermediary and also interpreter through whom God utters his oracle in direct divine speech. These oracles are spoken by God in his own person "with His prophet for interpreter" (Mos. 2.188). Or, as Philo explains more fully, "they are delivered through an interpreter, and interpretation and prophecy

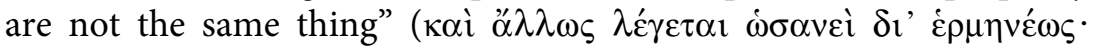

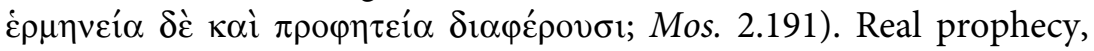
according to Philo, occurs only when a prophet does not merely function as an intermediary but also acts in accordance with his full potential as a prophet, even if it is God's inspiration which enables him to do so. Such oracles, as we will see shortly, make up the third kind, 
those which are spoken by Moses in his own person. As such, they fully contrast with the oracles spoken by God in his own person.

Between this pair of opposites, the second kind of oracles are those which Philo calls "the oracles of mixed character" (2.246) because they are the result of both divine and human input. They come about "through question and answer" (2.188):

In the second kind we find combination and partnership: the prophet asks questions of God about matters on which he has been seeking

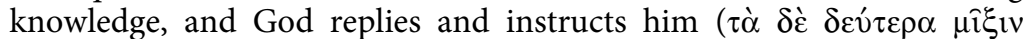

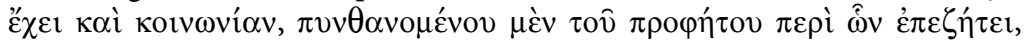

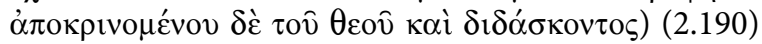

The first kind of oracle, occurring through direct divine speech, is also attested to by Paul on those occasions where he introduces quo-

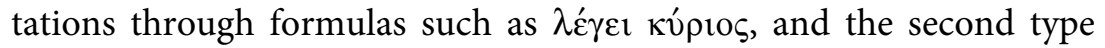
equally occurs in Paul, in Rom 11:3-4. In this passage, which we have already discussed in section one above, it is the prophet Elijah who poses a question to God, which God answers through a $\chi \rho \eta \mu \alpha \tau \imath \sigma \mu o ́ s$, an oracular response (Rom 11:2-4). This oracle is indeed understood as an interplay of prophetic questions and divine answers. The only difference between Paul and Philo is that the latter theorizes upon it, whereas Paul only presupposes such a differentiation between various kinds of oracles.

The third and last type which Philo mentions are the oracles which do not show the kind of interaction characteristic of the second type, but are spoken by Moses in his own person, in complete contrast to the first type. It is this third kind of oracle that Philo dwells upon in order to show that Moses "was a prophet of the highest quality" (2.187). They constitute Moses' prophetic authority. Although, as Philo says, "all things written in the sacred books are oracles delivered through Moses," the last type of oracles are "those which are more especially his" ( $\tau \grave{\alpha}$ i $\delta 1 \alpha i ́ \tau \varepsilon \alpha ; 2.188$ ). However, Philo concedes that these oracles only occur when Moses is "possessed by God and carried away out of

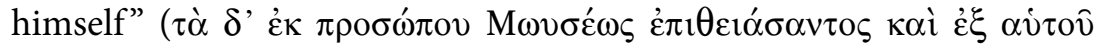
$\kappa \alpha \tau \alpha \sigma \chi \varepsilon \theta \dot{\varepsilon} v \tau o \varsigma ; 2.188)$ and that they are delivered "under divine inspiration" (2.246):

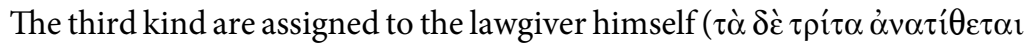

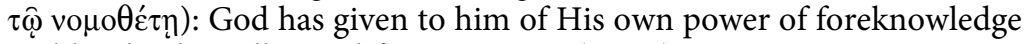
and by this he will reveal future events. (2.190) 
For that reason they are "spoken by Moses in his own person" (2.188). In these instances Moses is not merely an intermediary, as is the case when he delivers the first kind of oracles, instead:

...the speaker appears under that divine possession in virtue of which he

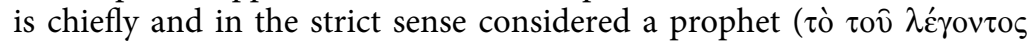

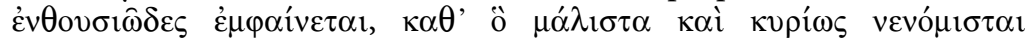

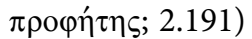

There seems to be an interesting analogy here with the reasoning in Pesher Habakkuk among the Dead Sea Scrolls. ${ }^{37}$ In this document, the author also regards the prophets as mere intermediaries of God's word, as is the case in Philo's first type of oracle. In contrast with these intermediary figures, there is another figure, which the author of the Pesher Habakkuk identifies as the Teacher of Righteousness, who offers an inspired interpretation of God's words to the prophets. Whereas the prophet Habakkuk lacked insight into the meaning of the words which he received from God, the Teacher of Righteousness perceived their proper meaning:

And God told Habakkuk to write what was going to happen to the last generation, but he did not let him know the end of the age. And as for what he says: 'So that the one who reads it may run' (Hab 2:2). Its interpretation concerns the Teacher of Righteousness, to whom God has disclosed all the mysteries of the words of his servants, the prophets. $(1 \mathrm{QpHab} 7: 1-5)^{38}$

In a sense, this characterization of the figure of the Teacher of Righteousness corresponds to Philo's portrayal of Moses in his real prophetic capacity - in which he does not just receive oracles but is able to utter them in his own person. At the same time, there may be a

\footnotetext{
${ }^{37}$ I owe this observation to Prof. Arie van der Kooij.

38 Translation from F. García Martínez, The Dead Sea Scrolls Translated: The Qumran Texts in English (trans. W.G.E. Watson; 2d ed.; Leiden: Brill and Grand Rapids, Mich.: Eerdmans, 1996), 200. The reverse phenomenon can also be seen in the Dead Sea Scrolls. Whereas the author of Pesher Habakkuk differentiates between the words of the prophets and their authoritative and inspired interpretation through the Teacher of Righteousness, the author of the Temple Scroll rewrites the Mosaic laws in direct divine speech. As G. Vermes, The Dead Sea Scrolls in English: Revised and Extended Fourth Edition (rev. and ext. 4th ed.; Sheffield: Sheffield Academic Press, 1995), 152 notes: "The aim of the redactor is to present the message of the scroll not as an interpretation of the Bible, but as an immediate divine revelation. For this purpose, not only does he formulate the supplementary legislation as directly spoken by God, but also regularly substitutes 'I' for 'the Lord = YHWH' of Scripture."
} 
difference. Although Philo acknowledges that Moses is only able to utter these oracles in his own person insofar as he is inspired, the thrust of the entire passage is that Moses is portrayed in his greatness as a prophet and acquires some independence from God. There appears to be a sliding scale of oracles which runs from those given in direct divine speech through "mixed oracles" in which God and human interrogators cooperate, to oracles which are more particularly assigned to Moses himself. Although "all things written in the sacred books are oracles delivered through Moses," the latter oracles "are more especially his" (2.188). Yet despite the relative independence of this last type of oracle, they do not run counter to God's oracles, as they are not Moses' own additional suggestions. This had been the case with Balaam, who, after giving the proper oracles of God, continues to provide his own personal counsel, for which Philo criticizes him:

The other (i.e. Balaam) replied: 'All that has been said hitherto was oracles from above. What I have now to say is suggestions of my own designing.' ... Hereby he convicted himself of the utmost impiety. For, 'Why', we might ask him, 'do you put forth your own personal counsels in opposition to the oracles of God? That were to hold that your projects are more powerful than the divine utterances.' (Mos. 1.294)

Clearly the difference between Balaam and Moses is that the latter, although he also speaks in his own person, still utters oracles because he speaks through inspiration. For this reason Philo emphasizes that "all things written in the sacred books are oracles delivered through Moses." However, having said that, it appears that Philo's distinction of three kinds of oracles shows that his understanding of the Jewish Scriptures is quite nuanced. For Philo, not all oracles are divine to the same degree, and the Mosaic writings do not fully coincide with these oracles but offer a narrative and interpretive framework for them. As Philo explains at the very end of his De vita Mosis, the full Mosaic writings are in fact also a kind of biographical memoir of Moses:

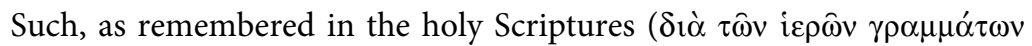
$\mu v \eta \mu \operatorname{ov}^{\prime} \varepsilon \tau \alpha \mathrm{l}$ ), was the life and such the end of Moses, king, lawgiver, high priest, prophet. (Mos. 2.292)

As our analysis shows, however, these Mosaic Scriptures are deemed holy because they have, at their heart, the holy oracles of God. 


\subsection{Philo and Paul in Comparison}

Much of this nuanced view can be recognized in Paul's letters. Paul also speaks of holy writings and mentions the prophets as their authors (Rom 1:2), he also differentiates between these prophets and the oracles which they report (Rom 11:4) and refers to oracles in divine direct speech, and he also knows of oracles which are uttered by God in a dialogue with man.

Moreover, the distinction between God's own words, given in the oracles, and the activities of the prophets seems to be so fundamental to Paul that he also applies it in his stipulation of the relationship between Jesus' authority and his own. As we can deduce from 1 Cor 7, Paul regards Jesus' ipsissima verba to have binding authority, whereas he seems to claim for his own words a lesser status. Several times Paul, while instructing the Corinthians on specific matters, confesses that he only expresses his own view and not that of Christ:

To the married I give this command-not I but the Lord (ov̉к $\dot{\varepsilon} \gamma \grave{\omega} \dot{\alpha} \lambda \lambda \grave{\alpha}$ o kv́pıs) - that...(1 Cor 7:10)

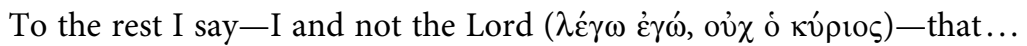
(1 Cor 7:12)

Now concerning virgins, I have no command of the Lord, but I give

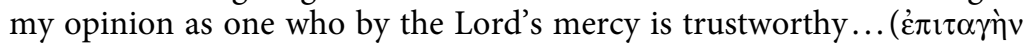

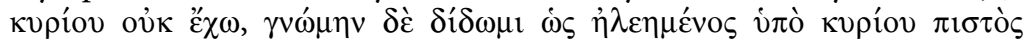
Eivol; 1 Cor 7:25)

A wife is bound as long as her husband lives. But if the husband dies, she is free to marry anyone she wishes, only in the Lord. But in my judgement she is more blessed if she remains as she is. And I think that I too

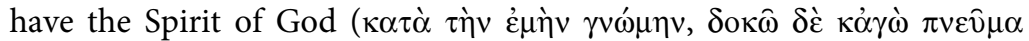
$\theta \varepsilon \circ \hat{\text { Ě } \chi \varepsilon เ v ; ~} 1$ Cor 7:39-40)

Whereas the words of Christ would be absolutely binding, Paul only gives his own judgement and opinion, although he seems to imply that his words are not only trustworthy but also inspired and prophetic insofar as he possesses the Spirit of God (1 Cor 7:40; cf. 1 Cor 14:6). ${ }^{39}$ Thus, Paul's prophetic words do not enjoy the same authority as Christ's "oracular" words. Whereas the oracular words of God and the ipsissima verba of Christ are unquestionably authoritative, the

\footnotetext{
39 On the relationship between Spirit and prophecies, see also 1 Thess 5:19-21: "Do not quench the Spirit. Do not despise the words of prophets," but test everything."
} 
authority of prophetic words remains open to further scrutiny. This holds true for the status of contemporary prophets in the early Christian community, with Paul encouraging his fellow Christians to critically assess the words of prophets:

Let two or three prophets speak, and let the others weigh what is said. If a revelation is made to someone else sitting nearby, let the first person be silent. For you can all prophesy one by one, so that all may learn and all be encouraged. And the spirits of prophets are subject to the prophets, for God is a God not of disorder but of peace. (1 Cor 14:29-33)

Paul's judgement of contemporary prophets does not seem to be principally different from his evaluation of the prophets of the Jewish Scriptures. Their power is secondary to the higher authority of the divine oracles and Christ. Prophetic authority is not as authoritative as oracular authority. In relation to "scriptural authority," it appears that for Paul this is not yet a major monolithic concept, which we seem to find in the categorical assertion made in Pseudo-Paul's 2 Tim 3:16 that

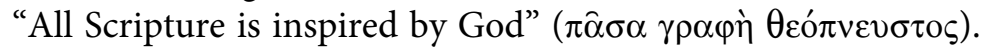

I will discuss the latter view in the final section below. In the case of Paul, there still seems to be a clear difference between ancestral, oracular and prophetic authority. This difference is a difference in the degree of gravity, in a way that is very similar to Philo's differentiation between three types of oracles. At this stage, neither Paul nor Philo hold a view on Scripture which regards each part as equally authoritative. However, below I will raise the question of whether my thesis-that Paul holds a very nuanced view on the Scriptures-is not contradicted by his conception of revelation and by his repeated statement that particular events happen "in accordance with the Scriptures."

\section{Contradictory Views?}

Paul's nuanced view of the difference in degrees of gravity of the various constituents of the holy writings does not seem to be contradicted by the fact that he regards Christ's death and resurrection as being "in accordance with the Scriptures," nor by particular references to these writings, such as "the word of God." I will briefly discuss these writings and also reflect on Paul's terminology of revelation. 


\section{1. "In Accordance with the Writings"}

In Paul's view, Christ's death and resurrection are "in accordance with

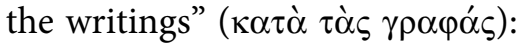

For I handed on to you as of first importance what I in turn had received: that Christ died for our sins in accordance with the Scriptures, and that he was buried, and that he was raised on the third day in accordance with the Scriptures. (1 Cor 15:3-4)

It seems to me that Paul's view that Christ's death and resurrection unfolded in accordance with the authoritative writings and were thus predicted, could well be a reference to specific oracular statements within these writings and thus fully in line with what we have found thus far. Paul's view on Christ's resurrection, for example, is largely based on Ps 110:1 where, in Paul's interpretation, at the instalment of Christ as Lord, God says to him in first person direct speech: "Sit at my right hand until I make your enemies a footstool for your feet" (see 1 Cor 15:25; Rom 8:34). For Paul, then, the fulfilment of such divine oracular statements at Christ's resurrection were indeed in accordance

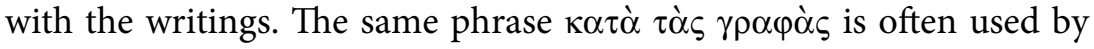
Galen to point to the congruence between something in reality and the way it has been described in various writings. ${ }^{40}$ In the case of Paul, the congruence between the events of Christ's death and resurrection, on the one hand, and their prediction in the authoritative writings, on the other, does not mean that these writings are revelatory as such and in their entirety. Rather, this prediction could be based on the actual divine oracles within these writings.

\section{2. "The word of God"}

Paul's subtle understanding of the authoritative value of the Jewish writings is not contradicted by the factual occurrence of the phrase

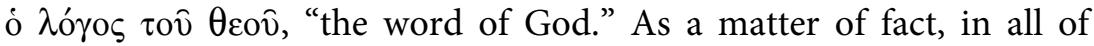
the passages where it occurs this phrase does not refer to the Jewish Scriptures but refers to the present preaching of the gospel. It is this preaching which is characterized as "the word of God," a clear

${ }^{40}$ See Galen, Comp. med. 13.995 .12 (Kühn); In Hip. epid. 17a.1006.4 (Kühn); 17b.111.1 (Kühn); In Hip. med. off. 18b.713.6 (Kühn); 18b.888.18 (Kühn). See also Apollonius Dyscolus, De constructione 2.2.155. 
instance of which is 1 Thess 2:13, where Paul writes to the ex-pagan Christian Thessalonians:

We also constantly give thanks to God for this, that when you received

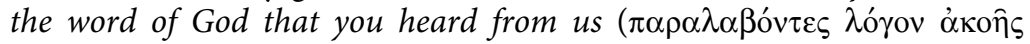
$\pi \alpha \rho$ ' $\dot{\eta} \mu \hat{\omega} v \tau o \hat{v} \theta \varepsilon \circ \hat{v})$, you accepted it not as a human word ( $\dot{\varepsilon} \delta \varepsilon \varepsilon^{\prime} \xi \sigma \theta \varepsilon$

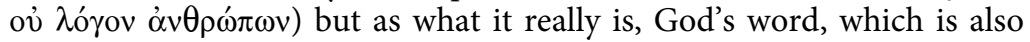

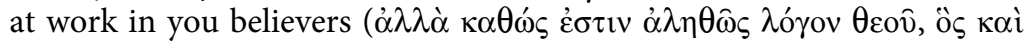

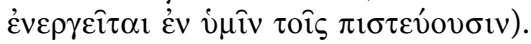

The "word of God" in this passage is not a reference to the authoritative writings of the Law and the Prophets, but stands for the preaching of the gospel which, as God's word, is contrasted with the $\lambda$ óros $\dot{\alpha} v \theta \rho \omega ́ \pi \omega v$.

In all other instances in which the phrase "the word of God" is used in Paul's letters, it also refers to the preaching of the gospel (1 Cor 14:36; 2 Cor 2:17; 4.2; Rom 9:6-7). Perhaps in some cases it is even ambiguous and should not necessarily be translated as "the word of God," but as "the word concerning God." This holds particularly true for 2 Cor 2:17 where Paul, in his polemics with the sophists within the Christian community at Corinth, denies that he has sold the word of God as a sophist would, receiving money for his preaching. In this context, "the word of God" could also be understood as Paul's word

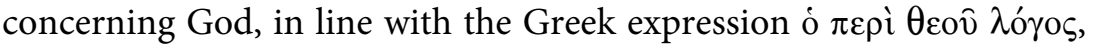
"the word about God." 41 Whatever the exact translation, however, it is clear that without exception Paul only uses this terminology in relation to the preaching of the gospel and not to the authoritative Jewish writings. This is fully parallel with the fact that he does not speak of these Jewish writings in terms of revelation, as we will see below. As

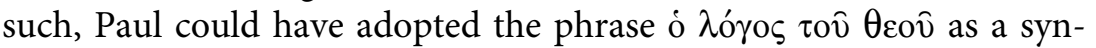

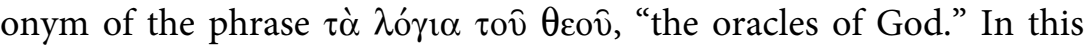

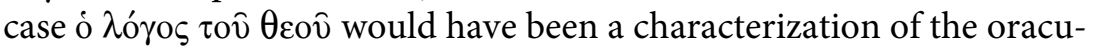
lar statements of God which Paul discerns within the Jewish writings (Rom 3:2; 11:4). The phrase could be used in this sense in Greek. Dio Chrysostom, for example, applied the phrase $\theta \varepsilon o \hat{v} \lambda$ ó ${ }^{\circ} \varsigma$ s to denote an utterance of the god Poseidon to Odysseus (Or. 64.12). Yet Paul refrained from using it in this sense and reserved it as a designation for the preaching of the gospel.

${ }^{41}$ Aristotle, Divisiones 50; Chrysippus, Fragmenta logica et physica 475; Plutarch, Sera 558D. Cf. also Aristob. fr. 1 Denis; Sib. Or. 3.1. 


\subsection{The Language of Revelation}

Just as "the word of God" does not refer to the Scriptures, neither does the language of revelation. Paul does not apply this language to the Jewish law, the Scriptures or the prophets. The relevant terminology

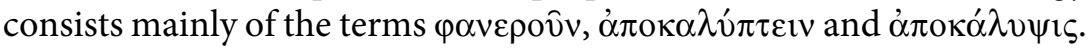
However, if Paul does not apply this language to the Jewish Scriptures, in what way does he use it?

It seems that Paul distinguishes between three important moments in a revelatory process which spans the entire period between creation and the end. In the midst of it, in the "fullness of time" (Gal 4:4), the revelation of Christ takes place. This is preceded, however, by the revelation of God himself, occurring since the beginning of creation. According to Paul:

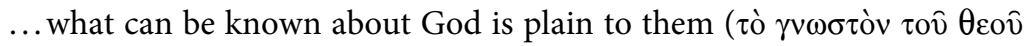

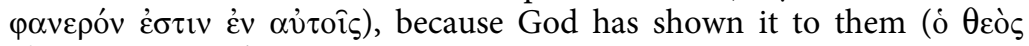

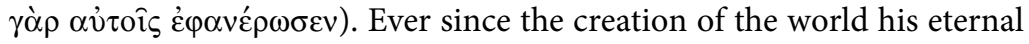
power and divine nature, invisible though they are, have been understood and seen through the things he has made. (Rom 1:19-20)

Paul returns to the language of revelation only when he speaks about the revelation of the gospel after the dominance of the Mosaic law. In this gospel the righteousness of God as it manifests itself in Jesus Christ is disclosed. Although Paul never qualifies the Law and the Prophets as revelatory, he does say that this righteousness of God is attested by the Law and the Prophets:

But now, irrespective of law, the righteousness of God has been dis-

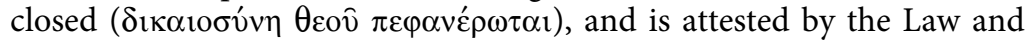

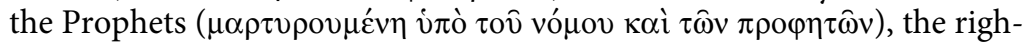
teousness of God through faith in Jesus Christ for all who believe. (Rom 3:21-22)

As Paul makes clear in his letter to the Galatians, the Law governs a temporary period prior to the moment in which the gospel is uncovered: "Now before faith came, we were imprisoned and guarded under the Law until faith would be revealed" (Gal 3:23). The Law itself is not characterized as revelatory, rather it is the gospel which is uncovered and revealed. Indeed, the gospel is the bearer of God's $\dot{\alpha} \pi$ oкó $\lambda v \psi 1 \varsigma$ :

I am not ashamed of the gospel; it is the power of God for salvation to everyone who has faith, to the Jew first and also to the Greek. For in

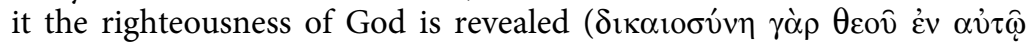


$\dot{\alpha} \pi$ ок $\left.\alpha \lambda v^{\prime} \pi \tau \varepsilon \tau \alpha 1\right)$ through faith for faith; as it is written, 'The one who is righteous will live by faith (Hab 2:4)'. (Rom 1:16-17)

Again, we see the same ambiguity. Just as the righteousness of God "is attested by the Law and the Prophets" (3:21), it has indeed already been described in the Jewish Scriptures in the book of Habakkuk. Yet it is only its manifestation in the gospel which is qualified as revelation: "in it the righteousness of God is revealed."

As a result of this revelation of the gospel, the manifestation of Christ to Paul is also seen as a revelation (Gal 1:12;16). Moreover, God is said to make this new knowledge about him known in every place through Paul's preaching (2 Cor 2:14-16). Even Paul's own life makes the life of Christ manifest (2 Cor 4:10-11). As regards the contents on which Paul reflects in his preaching, these are alluded to in the Jewish Scriptures, which include writings which were later regarded as noncanonical, as the following quotation from the Apocalypse of Elijah makes clear:

... as it is written, 'What no eye has seen, nor ear heard, nor the human heart conceived, what God has prepared for those who love him'-these

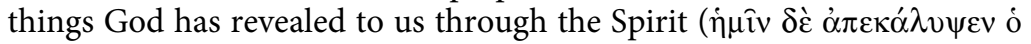

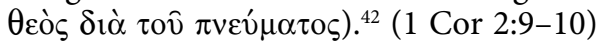

Yet again, there is talk of revelation only once those things alluded to in the Jewish writings surface in the time when the gospel is preached. Thus, Paul's concept of revelation and of the gospel has to this point nothing to do with literary writing. It is not attributed to the Jewish Scriptures but relates to God's manifestation in the works of creation and in the advent of Christ. This also holds true for a third application of the terminology of revelation, that is to the end of time.

According to Paul, it is Christ "who will bring to light ( the things now hidden in darkness and will disclose the purposes of the heart" (1 Cor 4:5). Or as he phrases it elsewhere, "all of us must be revealed ( $\varphi \alpha v \varepsilon \rho \omega \theta \eta \bar{\eta} v \alpha \hat{i})$ before the judgement seat of Christ, so that each may receive recompense for what has been done in the body, whether good or evil" (2 Cor 5:10). These and various other passages show that "revelation" is also an eschatological term-it relates to the eschatological revelation of Jesus Christ, the revelatory character of the

\footnotetext{
${ }^{42}$ Quotation ascribed to the Apocalypse of Elijah by Origen.
} 
day of judgement and the eschatological disclosure of the Christians themselves, who find their true, glorious identity. ${ }^{43}$

Paul not only knows about these clearly structured moments of God's manifestation in creation, Christ's manifestation in "the fullness of time" and the still outstanding revelatory moment at the end of time, but also about the present practices of revelation within the Christian community. Paul tells the Corinthians that he refrains from speaking in tongues in the community but instructs them through either revelation, knowledge, prophecy or teaching:

Now, brothers and sisters, if I come to you speaking in tongues, how will I benefit you unless I speak to you in some revelation or knowledge or

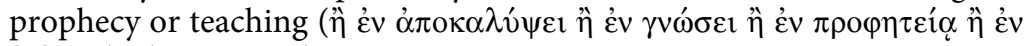
$\delta เ \delta \alpha \chi \hat{n})$ ? (1 Cor 14:6)

He continues, stating that other members of the community also engage in such practice themselves, notably in offering revelations:

When you come together, each one has a hymn, a lesson, a revelation ( $\dot{\alpha} \pi$ oќ́ $\lambda v \psi v v)$, a tongue, or an interpretation. Let all things be done for building up (1 Cor 14:26)

For practical reasons, Paul advises them that "[i]f a revelation is made ( $\dot{\alpha}$ ок $\alpha \lambda \nu \varphi \theta \hat{n})$ to someone else sitting nearby, let the first person be silent" (1 Cor 14.30). These and other passages convey that, for Paul, revelation was a current activity in the Christian communities, with both Paul himself and others being the recipients of divine revelations. ${ }^{44}$

Because Paul acknowledges the current practice of revelations within the Christian communities, it is all the more staggering that he never applies the terminology of revelation to the Jewish Scriptures. These Scriptures, the Law and the Prophets may attest to the righteousness of God as revealed in the gospel, but they are not themselves seen as revelation. They also include non-canonical examples, such as the Apocalypse of Elijah, which may contain a eulogy on "what no eye has seen," but is only styled as revelation when manifest in the gospel. It is important to emphasize that revelation in the gospel is not literary. According to Paul there is no literary form of revelation. Revelation typically takes places in reality, either in the works of creation, in the manifestation of Christ through his birth in "the fullness of time," in

${ }^{43}$ See further 1 Cor $1: 7 ; 3: 13$; Rom $2: 5$, Rom $8: 18-19$.
${ }^{44}$ See further 2 Cor $12: 1,7$; Phil $3: 15$; Gal 2:2. 
the experience of the community or in the revelatory process related to the end of time. There is as yet no literary dimension to Paul's concept of revelation.

Nevertheless, it is very odd that apart from the works of creation nothing in the past, as narrated in the Jewish Scriptures, qualifies as revelation. One could argue that this is due to the polemics in which Paul is involved with non-Christian Jews-in such a dispute Paul would naturally downplay the revelatory importance of the Jewish Scriptures. Yet this does not provide a full explanation, as Paul did not see himself as a separatist Christian but as completely Jewish. Of course, in his polemics, as with many other Jews, Paul was engaged in his own kind of historiography as a means of stating his case for his kind of Judaism. However, this does not seem to account for his hesitance in applying the language of revelation to the Jewish Scriptures. Rather, as we have already seen, Paul attributes the various Jewish Scriptures to their human, prophetic author and it is only the direct oracular speeches of God in these writings that Paul regards as the words of God as such.

\section{Final Considerations and Conclusion}

Our observation that Paul did not regard the authoritative Jewish writings as revealed and inspired in themselves can be maintained. Neither Paul nor Philo expresses a belief in scriptural inspiration. As we have seen, only the oracular statements of God contained in these writings were to be regarded as divine in the proper sense of the word. Philo distinguished various kinds of oracles. In addition to the oracles of direct divine speech which was spoken by God in his own person, he also distinguished oracles which allowed room for human-divine cooperation and presupposed that the prophet, although inspired, spoke in his own person. Paul, in his turn, did not identify the writings as "the word of God" but attributed them to human authors, either to Moses, the author of the ancestral law, or to the prophets who, like Moses, included the divine oracles within their writings and, by doing so, gave them a historical and interpretative context. For Paul, "scriptural authority" was complex, with the ancestral authority of particular respectable traditions and figures, the divine authority of oracles and the authority of decent prophets all contributing to its weight. First and foremost, the Jewish writings gave access to history and to 
the divine oracles which humanity had received during that history. According to Paul, these writings were authoritative and even holy, insofar as they contained the oracles of God.

This nuanced view of Scripture seems to be modified in $2 \mathrm{Tim}$, in the famous passage about the divine inspiration of all Scripture. The relevant passage reads:

But as for you, continue in what you have learned and firmly believed, knowing from whom you learned it, and how from childhood you have

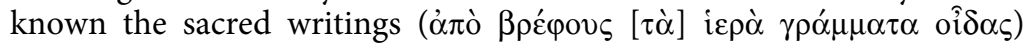
that are able to instruct you for salvation through faith in Christ Jesus. All Scripture is inspired by God and is* useful for teaching, for reproof, for correction, and for training in righteousness, so that everyone who belongs to God may be proficient, equipped for every good work. (2 Tim 3:14-17)

It seems very likely that this passage represents a step towards a theology of scriptural inspiration on the level of the Scriptures themselves. However, that this is the case depends on the translation. Because the line "All Scripture is inspired by God and is useful for teaching" lacks

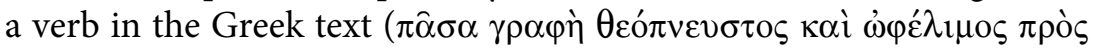
$\delta 1 \delta \alpha \sigma \kappa \alpha \lambda i \alpha v)$, two translations are possible, as is generally recognized in the commentaries: (1) "All scripture [is] inspired by God and [is] useful for teaching" (NRSV); or (2) "Every scripture inspired by God [is] also useful for teaching" (alternative reading in the margin of the NRSV). The latter translation, though possible, is usually disregarded because it is considered to express the strange view that Scripture is only partially revealed. According to Clare Drury's commentary in The Oxford Bible Commentary, for example:

If the NRSV translation of 3:16 is taken, the usefulness of all Scripture arises from the fact that it is divinely inspired. The alternative reading in the margin assumes that only those passages inspired by God are useful, i.e. it assumes that some parts are not so inspired. This was indeed the belief among some early Gnostic groups such as the Marcionites, so it makes most sense to follow the NRSV translation. It is the usefulness of Scripture that is the significant point. ${ }^{45}$

Although I agree with Drury that the NRSV translation is to be preferred on account of the generally acknowledged anti-gnostic stance

\footnotetext{
${ }^{45}$ J. Barton and J. Muddiman, eds., The Oxford Bible Commentary (Oxford: Oxford University Press, 2001), 1230.
} 
of the Pastoral Epistles, it is nevertheless not entirely correct to say, without further qualification, that the view that "only those passages inspired by God are useful" is gnostic. In a sense, it was also Paul's view that various parts of Scripture had their own degrees of gravity, depending on whether their authority was ancestral, oracular or prophetic. Furthermore, this difference in degrees of gravity gave Paul the freedom to distinguish between positive and negative aspects of Moses. On the one hand he is critical of Moses' ethnocentric law and discredits it, as we have seen, as being a late-comer to Israel, 430 years after Abraham (Gal 3:15-17). Yet, on the other hand he is aware of the fact that Moses is the author of the Mosaic law in the broad sense, which includes the narratives concerning Adam and Abraham, who are exemplary figures for Paul. For that reason Paul takes care not to limit Moses to being the author of the Sinaitic law, but also considers him to be the author of "the entire law," as Gal 5:3, 14 make clear. In that capacity as the author of the Pentateuch, Moses is, as we have seen, not only the one who reports "the righteousness that comes from the Law" but also the one who gives voice to "the righteousness that comes from faith" (Rom 10:5-8). He is not only the author of the Mosaic law in the strict sense but also narrates "the law of the spirit of life," the anthropological law which is very relevant to Paul because it crowns humanity's constitution of body and soul with a spirit-a view which Paul derives from the second account of humanity's creation in Gen 2:7 (Rom 8:2; cf. 1 Cor 15:45). ${ }^{46}$ Such an ambiguous relationship to Moses, however, is only possible because Paul does not equate the Mosaic writings with revelation. These writings have various aspects. The Jewish Scriptures are not just revelatory but also ancestral; not just divine but also prophetic. For that reason, the translation "Every Scripture inspired by God [is] also useful for teaching" could well be possible within the Pauline view. The Scriptures are not useful for teaching in their entirety but only insofar as they have been inspired by God.

Yet, given the anti-gnostic polemics of the Pastoral Epistles, it seems most likely that the author of 2 Tim attacks the gnostic categorical criticism of the Old Testament writings. It seems to be this gnostic criticism of the Scriptures which triggered his response, and in this context the translation "All scripture [is] inspired by God and [is]"

\footnotetext{
${ }^{46}$ On this, cf. van Kooten, Paul's Anthropology in Context.
} 
useful for teaching" (NRSV) makes perfect sense. ${ }^{47}$ This categorical affirmation of the inspired nature of all Scripture, however, is just the response provoked by the gnostics' lack of appreciation of the Jewish writings, which were seen as either false because they were written from the wrong perspective (Marcion), or as the corruption of an original revelation (Apelles, Adimantus and Mani). ${ }^{48}$ Although understandable in this new polemical context, the statement by the author of 2 Tim has done much to obscure Paul's nuanced view of the nature of the holy writings.

${ }^{47}$ See also Y.-M. Blanchard, “'Toute Écriture est inspirée’ (2 Tm 3,16): Les problématiques de la canonisation et de l'inspiration, avec leurs enjeux respectifs," RSR 93 (2005): 497-515.

${ }^{48}$ On this issue see J.A. van den Berg, Biblical Argument in Manichaean Missionary Practice: The Case of Adimantus and Augustine (Leiden: Brill, 2010), 168-73. The view that the Jewish writings are a corruption of an original revelation is also expressed in the Qur'an, in Sura 2. Cf. S.H. Griffith, "The Bible and the 'People of the Book,'” Bulletin Dei Verbum 79/80 (2006): 22-30. 